\title{
Insights into the pathogenesis of herpes simplex encephalitis from mouse models
}

\author{
Mathieu Mancini ${ }^{1,2} \cdot$ Silvia M. Vidal ${ }^{1,2}$
}

Received: 13 April 2018 / Accepted: 9 August 2018 / Published online: 23 August 2018

(c) The Author(s) 2018

\begin{abstract}
A majority of the world population is infected with herpes simplex viruses (HSV; human herpesvirus types 1 and 2). These viruses, perhaps best known for their manifestation in the genital or oral mucosa, can also cause herpes simplex encephalitis, a severe and often fatal disease of the central nervous system. Antiviral therapies for HSV are only partially effective since the virus can establish latent infections in neurons, and severe pathological sequelae in the brain are common. A better understanding of disease pathogenesis is required to develop new strategies against herpes simplex encephalitis, including the precise viral and host genetic determinants that promote virus invasion into the central nervous system and its associated immunopathology. Here we review the current understanding of herpes simplex encephalitis from the host genome perspective, which has been illuminated by groundbreaking work on rare herpes simplex encephalitis patients together with mechanistic insight from single-gene mouse models of disease. A complex picture has emerged, whereby innate type I interferon-mediated antiviral signaling is a central pathway to control viral replication, and the regulation of immunopathology and the balance between apoptosis and autophagy are critical to disease severity in the central nervous system. The lessons learned from mouse studies inform us on fundamental defense mechanisms at the interface of host-pathogen interactions within the central nervous system, as well as possible rationales for intervention against infections from severe neuropathogenic viruses.
\end{abstract}

\section{Introduction}

Herpes simplex virus types 1 and 2 (HSV-1 and HSV-2) are among the most common human pathogens. These viruses can establish life-long latency, such that an estimated 3.7 billion people under age $50(67 \%)$ have been infected with HSV-1 and 417 million people aged 15-49 (11\%) with HSV2, worldwide (Looker et al. 2015a). There are important geographical differences however, where HSV-1 is universal in the developing world and in the United States, and HSV-2 is most prevalent in Africa (Looker et al. 2015b). HSV-2 disproportionally affects women and increases the risk of acquiring the human immunodeficiency virus (McQuillan et al. 2018). HSV infections are generally confined to

Silvia M. Vidal

silvia.vidal@mcgill.ca

1 Department of Human Genetics, McGill University, Montreal, QC, Canada

2 McGill Research Centre on Complex Traits, McGill University, 3649 Promenade Sir William Osler, Montreal, QC H3G 0B1, Canada the oro-labial and genital skin and mucosa, although the viruses are the most frequent cause of sporadic encephalitis (Looker et al. 2017; Steiner and Benninger 2013), a potentially deadly infection of the central nervous system (CNS). The characteristic clinical presentation of HSV encephalitis usually consists of fever, seizures, and often focal or generalized neurological deficits depending on the clinical form, namely neonatal HSV or herpes simplex encephalitis (HSE). In neonatal HSV, brain involvement is generalized, and the usual cause is HSV-2 (Long et al. 2011), which is acquired at the time of delivery in incident mothers. Post-partum infection is thought to be acquired by contact with HSV-1 shed by caregivers (10\% of cases). HSV-1 is the predominant cause of HSE, with $10 \%$ of the cases caused by HSV-2 (Solomon et al. 2012). HSE typically affects the frontal and temporal lobes (Kaewpoowat et al. 2016), but in rare cases, the brainstem may be preferentially involved (Livorsi et al. 2010). The age-specific incidence is bimodal, with about $1 / 3$ of cases observed in children between 3 months and 20 years, and the other in adults over 60 , representing approximately $2 / 3$ of the cases. Before the advent of acyclovir and other antiviral therapies, the mortality rate associated with central 
HSV infection was $70 \%$. Treatment is effective if started promptly; in contrast, delays in treatment can be devastating. It is striking that in HSE, which still has a mortality approaching $30 \%$ and causes serious brain damage, there have been no significant enhancements of therapy in the last 30 years (Haubenberger and Clifford 2016). Improved tools are needed to treat, diminish the risk of, and prevent HSE based on a molecular understanding of HSE disease mechanisms.

Although there have been important advances in understanding disease neuropathogenesis [reviewed in Koyuncu et al. (2013), Kramer and Enquist (2013)], the precise mechanisms leading to HSE are not known. The virus enters the body by infecting epithelial or mucosal cells in peripheral tissues before entering sensory neurons. The virus genome reaches the soma of the sensory neuron as an episome that expresses a single transcript, LAT, and several microRNAs. The LAT RNA counteracts apoptosis of the neuronal cell and allows maintenance of the viral genome (Ahmed et al. 2002). The virus also has mechanisms (ICP34.5) that counteract autophagy, another antiviral mechanism in neurons (Orvedahl et al. 2007). During active replication, the virus expresses proteins (ICP0) that block innate responses mediated by type I interferon (IFN I), preventing the activation of the innate antiviral response (Lin et al. 2004). If the infection is not rapidly controlled, inflammatory responses are triggered and IFNs activate NK cell and T cell responses that are critical to clearance but also need to be tightly controlled to prevent inflammatory damage in the CNS (Menendez and Carr 2017). Pathological studies show that HSE is associated with virus replication, neuronal cell death, and the presence of inflammatory infiltrates; however, the relative contribution of each response to pathology or defense is not entirely clear (Michael et al. 2016; Wnek et al. 2016). Also outstanding is the question of which cellular and viral determinants can restrict replication at mucosal sites of infection, or permit the rare escape of virus to the CNS.

Host and viral genetic factors may interact to cause variability of herpesvirus neurovirulence. Genetic differences in isolates from HSE patients and oro-labial infections indicated that at least half of the cases of HSE are caused by a different viral strain than the one responsible for cold sores in the same individual, suggesting that HSE is due to primary infection rather than reactivation (Steiner 2011). Advancements in high-throughput sequencing have now made it possible to study the full extent of genetic variation in the viral population within an infected host, or that being transmitted between different hosts (Pandey et al. 2017; Parsons et al. 2015), and to provide the potential molecular basis for neurovirulence.

In recent years, the clinical genetic study of patients and families with HSE has revealed that single-gene inborn errors of innate or cell-intrinsic immunity can underlie enhanced susceptibility to specific viral infections in otherwise healthy individuals. Unique aspects of HSE molecular pathology have also been clarified with the advent of next-generation sequencing technologies. Thus, it was shown that HSE in two children was the consequence of an autosomal recessive deficiency in the intracellular protein UNC93B1 leading to impaired cellular IFN I responses (Casrouge et al. 2006). Subsequent work has confirmed that HSE in children may result from single-gene errors in Toll-like receptor 3 (TLR3)-IFN I pathways (Herman et al. 2012; Perez de Diego et al. 2010; Sancho-Shimizu et al. 2011; Zhang et al. 2007). These genetic defects all lead to reduced IFN I induction in patient cells, upon HSV-1 infection or ex vivo stimulation of the TLR3 pathway, in both fibroblasts and specific CNS cell lineages derived from induced pluripotent cells from the patient (Lafaille et al. 2012). Whereas defects in the TLR3 pathway are remarkably specific for manifestations of HSE caused by HSV-1, some patients have immunodeficiencies to various infectious phenotypes. Patients with susceptibility to herpes and mycobacterial infections have mutations in the transcription factor STAT1 and in NF- $\mathrm{\kappa B}$ essential modulator NEMO (Audry et al. 2011; Dupuis et al. 2003). More recently, several patients with brainstem-localized HSV1 , norovirus, or influenza virus infections were found to lack intrinsic antiviral immunity due to mutations in the RNA binding protein, DBR1 (Zhang et al. 2018). Why such genetic determinants should manifest in childhood, but not in adult HSE, is unclear.

These groundbreaking discoveries (recently reviewed in (Casanova 2015; Zhang et al. 2013b)) have clarified the critical protective role of innate IFN responses that are non-redundant in the immune system. Specific mutations in components of the innate response account only for a minority of patients and fail to explain completely the different disease manifestations in the newborn HSV, childhood HSE, and the elderly population. Four decades ago, Lopez et al. reported that the infection of inbred mouse strains with HSV-1 mimicked dramatic differences in the presentation of encephalitis and survival observed in humans, justifying the search of genetic determinants of pathogenesis in mice (Lopez 1975). Whereas the phenotypes of human mutations have been recapitulated in mouse models for the most part, studies in mice have led to the discovery of new cell-intrinsic (Table 1) and immune cell-mediated (Table 2) disease mechanisms. This review will focus on how mouse models have contributed to our understanding of HSE and on the contributions of host genetics and of Trl3-dependent and independent mechanisms to HSV antiviral immunity. We also discuss future perspective on how these discoveries may lead to the development of improved therapies tailored to specific forms of human HSE. 
Table 1 Gene deficiencies affecting cell-intrinsic responses to HSV encephalitis in mice, and to other infections in humans

\begin{tabular}{|c|c|c|c|c|c|c|c|c|c|}
\hline $\begin{array}{l}\text { Targeted } \\
\text { allele(s) }\end{array}$ & Protein & Function & $\begin{array}{l}\text { Survival } \\
\text { phenotype }\end{array}$ & Virus & $\begin{array}{l}\text { Infection } \\
\text { route }\end{array}$ & References & Human gene & $\begin{array}{l}\text { Infectious } \\
\text { agent or } \\
\text { disease }\end{array}$ & $\begin{array}{l}\text { OMIM } \\
\text { number }\end{array}$ \\
\hline Pvrl1 $^{-/-}$ & Nectin-1 & $\begin{array}{l}\text { Cell-surface } \\
\text { HSV entry } \\
\text { receptor }\end{array}$ & Resistant & HSV-2 & Intracranial & $\begin{array}{l}\text { Kopp et al. } \\
\text { (2009) }\end{array}$ & & & \\
\hline \multirow[t]{2}{*}{ Ifnar ${ }^{-1-}$} & $\mathrm{IFN} \alpha / \beta \mathrm{R} 1$ & $\begin{array}{l}\text { Type I IFN } \\
\text { receptor }\end{array}$ & Susceptible & HSV-1 & Intracranial & $\begin{array}{l}\text { Wang et al. } \\
\text { (2012) }\end{array}$ & IFNAR2 & $\begin{array}{l}\text { Disseminated } \\
\text { vaccine } \\
\text { measles, } \\
\text { HHV-6 }\end{array}$ & 602376 \\
\hline & & & Susceptible & HSV-2 & Intravaginal & $\begin{array}{l}\text { Lee et al. } \\
\text { (2017), } \\
\text { Reinert } \\
\text { et al. }(2012)\end{array}$ & & & \\
\hline$T l r 3^{-/-}$ & TLR3 & $\begin{array}{l}\text { Endosomal } \\
\text { pattern } \\
\text { recognition } \\
\text { receptor }\end{array}$ & Susceptible & HSV-2 & Intravaginal & $\begin{array}{l}\text { Reinert et al. } \\
\text { (2012) }\end{array}$ & $T L R 3$ & HSV-1 & 603029 \\
\hline \multirow[t]{2}{*}{ Ticam1 $^{-/-}$} & TRIF & $\begin{array}{l}\text { TLR3 cas- } \\
\text { cade adap- } \\
\text { tor protein }\end{array}$ & Susceptible* & HSV-1 & Intranasal & $\begin{array}{l}\text { Menasria } \\
\text { et al. (2013) }\end{array}$ & TICAM1 & $\begin{array}{l}\text { HSV-1, } \\
\text { HSV-2 }\end{array}$ & 607601 \\
\hline & & $\begin{array}{l}\text { STING } \\
\text { cascade } \\
\text { adaptor } \\
\text { protein }\end{array}$ & Susceptible* & HSV-1 & Corneal & $\begin{array}{l}\text { Wang et al. } \\
\text { (2016) }\end{array}$ & & & \\
\hline$T l r 4^{-1-}$ & TLR4 & $\begin{array}{l}\text { Cell-surface } \\
\text { pattern } \\
\text { recognition } \\
\text { receptor }\end{array}$ & As WT & HSV-1 & $\begin{array}{l}\text { Intraperito- } \\
\text { neal }\end{array}$ & $\begin{array}{l}\text { Kurt-Jones } \\
\text { et al. (2004) }\end{array}$ & & & \\
\hline \multirow[t]{3}{*}{$T l r 2^{-/-}$} & TLR2 & $\begin{array}{l}\text { Cell-surface } \\
\text { pattern } \\
\text { recognition } \\
\text { receptor }\end{array}$ & As WT & HSV-1 & Intranasal & $\begin{array}{l}\text { Lima et al. } \\
\text { (2010) }\end{array}$ & & & \\
\hline & & & Resistant & HSV-1 & $\begin{array}{l}\text { Intraperito- } \\
\text { neal }\end{array}$ & $\begin{array}{l}\text { Kurt-Jones } \\
\text { et al. (2004) }\end{array}$ & & & \\
\hline & & & Resistant & HSV-1 & Intracranial & $\begin{array}{l}\text { Wang et al. } \\
\text { (2012) }\end{array}$ & & & \\
\hline \multirow[t]{2}{*}{$\operatorname{Tlr} 9^{-/-}$} & TLR9 & $\begin{array}{l}\text { Endosomal } \\
\text { pattern } \\
\text { recognition } \\
\text { receptor }\end{array}$ & Susceptible* & HSV-1 & Intranasal & $\begin{array}{l}\text { Lima et al. } \\
(2010)\end{array}$ & & & \\
\hline & & & As WT & HSV-1 & Intracranial & $\begin{array}{l}\text { Wang et al. } \\
\text { (2012) }\end{array}$ & & & \\
\hline \multirow[t]{2}{*}{$T l r 2^{-/-} T \operatorname{Tl} 9^{-/-}$} & TLR2/9 & See above & Susceptible & HSV-1 & Intranasal & $\begin{array}{l}\text { Lima et al. } \\
(2010)\end{array}$ & & & \\
\hline & & & As WT & HSV-1 & Intracranial & $\begin{array}{l}\text { Wang et al. } \\
\text { (2012) }\end{array}$ & & & \\
\hline$U n c 93 b 1^{3 d}$ & UNC93B1 & $\begin{array}{l}\text { TLR cascade } \\
\text { adaptor } \\
\text { protein }\end{array}$ & As WT & HSV-1 & Intracranial & $\begin{array}{l}\text { Wang et al. } \\
\text { (2012) }\end{array}$ & UNC93B1 & HSV-1 & 608204 \\
\hline \multirow[t]{2}{*}{ Myd $88^{-/-}$} & MYD88 & $\begin{array}{l}\text { TLR cascade } \\
\text { adaptor } \\
\text { protein }\end{array}$ & Susceptible & HSV-1 & Intranasal & $\begin{array}{l}\text { Mansur et al. } \\
\text { (2005) }\end{array}$ & MYD88 & $\begin{array}{l}\text { Bacterial } \\
\quad(\text { pyogenes })\end{array}$ & 602170 \\
\hline & & & Resistant & HSV-1 & Intravenous & $\begin{array}{l}\text { Honda et al. } \\
\text { (2005) }\end{array}$ & & & \\
\hline$M b 21 d 1^{-1-}$ & cGAS & $\begin{array}{l}\text { Cytosolic } \\
\text { DNA sen- } \\
\text { sor }\end{array}$ & Susceptible & HSV-1 & Corneal & $\begin{array}{l}\text { Reinert et al. } \\
\text { (2016) }\end{array}$ & & & \\
\hline
\end{tabular}


Table 1 (continued)

\begin{tabular}{|c|c|c|c|c|c|c|c|c|c|}
\hline $\begin{array}{l}\text { Targeted } \\
\text { allele(s) }\end{array}$ & Protein & Function & $\begin{array}{l}\text { Survival } \\
\text { phenotype }^{\dagger}\end{array}$ & Virus & $\begin{array}{l}\text { Infection } \\
\text { route }\end{array}$ & References & Human gene & $\begin{array}{l}\text { Infectious } \\
\text { agent or } \\
\text { disease }\end{array}$ & $\begin{array}{l}\text { OMIM } \\
\text { number }^{\S}\end{array}$ \\
\hline Sting $g^{g t / g t}$ & STING & $\begin{array}{l}\text { Cytosolic } \\
\text { DNA sen- } \\
\text { sor }\end{array}$ & Susceptible & HSV-1 & Corneal & $\begin{array}{l}\text { Reinert et al. } \\
\text { (2016) }\end{array}$ & & & \\
\hline \multirow[t]{2}{*}{ Sting $^{-/-}$} & STING & $\begin{array}{l}\text { IFN } \\
\text { I-dependent } \\
\text { autophagy }\end{array}$ & As WT & HSV-1 & Corneal & $\begin{array}{l}\text { Parker et al. } \\
\text { (2015) }\end{array}$ & & & \\
\hline & & & Susceptible & HSV-1 & $\begin{array}{l}\text { Intravenous/ } \\
\text { intracranial }\end{array}$ & $\begin{array}{l}\text { Parker et al. } \\
\text { (2015) }\end{array}$ & & & \\
\hline $\operatorname{Trim} 14^{-1-}$ & TRIM14 & $\begin{array}{l}\text { Modifier of } \\
\text { cGAS }\end{array}$ & Susceptible* & HSV-1 & Intravenous & $\begin{array}{l}\text { Chen et al. } \\
\text { (2016) }\end{array}$ & & & \\
\hline Usp $13^{-1-}$ & USP13 & $\begin{array}{l}\text { Modifier of } \\
\text { STING }\end{array}$ & Resistant & HSV-1 & Intravenous & $\begin{array}{r}\text { Sun et al. } \\
(2017 a)\end{array}$ & & & \\
\hline $\begin{array}{l}\text { Usp2 } 1^{f l f l} \text { Lyz2- } \\
\text { cre }\end{array}$ & USP21 & $\begin{array}{l}\text { Modifier of } \\
\text { STING }\end{array}$ & Resistant & HSV-1 & Intravenous & $\begin{array}{l}\text { Chen et al. } \\
\text { (2017) }\end{array}$ & & & \\
\hline$R h b d f 2^{-/-}$ & iRhom2 & $\begin{array}{l}\text { STING } \\
\text { signaling } \\
\text { cascade }\end{array}$ & Susceptible & HSV-1 & Intravenous & $\begin{array}{l}\text { Luo et al. } \\
\text { (2016) }\end{array}$ & & & \\
\hline $\mathrm{Mavs}^{-1-}$ & $\begin{array}{l}\text { IPS-1 } \\
\quad \text { (MAVS) }\end{array}$ & $\begin{array}{l}\text { RIG-I/MDA5 } \\
\text { cytosolic } \\
\text { RNA sens- } \\
\text { ing pathway }\end{array}$ & As WT & HSV-1 & Intranasal & $\begin{array}{l}\text { Menasria } \\
\text { et al. (2013) }\end{array}$ & & & \\
\hline \multirow[t]{2}{*}{$\operatorname{Irf3} 3^{-1-}$} & IRF3 & $\begin{array}{l}\text { IFN signaling } \\
\text { transcrip- } \\
\text { tion factor }\end{array}$ & Susceptible* & HSV-1 & Corneal & $\begin{array}{l}\text { Murphy et al. } \\
\text { (2013) }\end{array}$ & $I R F 3$ & HSV-1 & 616532 \\
\hline & & & As WT & HSV-1 & Intravenous & $\begin{array}{l}\text { Honda et al. } \\
(2005)\end{array}$ & & & \\
\hline \multirow[t]{2}{*}{$\operatorname{Irf} 7^{-1-}$} & IRF7 & $\begin{array}{l}\text { IFN signaling } \\
\text { transcrip- } \\
\text { tion factor }\end{array}$ & Susceptible & HSV-1 & Corneal & $\begin{array}{l}\text { Murphy et al. } \\
\text { (2013) }\end{array}$ & $I R F 7$ & $\begin{array}{l}\text { Severe } \\
\text { influenza } \\
\text { disease }\end{array}$ & 605047 \\
\hline & & & Susceptible & HSV-1 & Intravenous & $\begin{array}{l}\text { Honda et al. } \\
\text { (2005) }\end{array}$ & & & \\
\hline $\operatorname{Irf} 3^{-1-} \operatorname{Irf} 7^{-1-}$ & IRF3/7 & See above & Susceptible & HSV-1 & Corneal & $\begin{array}{l}\text { Murphy et al. } \\
\text { (2013) }\end{array}$ & & & \\
\hline$R n f 128^{-/-}$ & RNF128 & $\begin{array}{l}\text { Modifier of } \\
\text { TBK1 }\end{array}$ & Susceptible & HSV-1 & Intravenous & $\begin{array}{l}\text { Song et al. } \\
\text { (2016) }\end{array}$ & & & \\
\hline$H c f c 2^{f l s / f l s}$ & $\mathrm{HCFC} 2$ & $\begin{array}{l}\text { Facilitates } \\
\text { IRF1/IRF2 } \\
\text { binding } \\
\text { to Tlr3 } \\
\text { promoter }\end{array}$ & Susceptible & HSV-1 & Retro-orbital & $\begin{array}{l}\text { Sun et al. } \\
\text { (2017b) }\end{array}$ & & & \\
\hline \multirow[t]{3}{*}{ Stat $1^{-/-}$} & STAT1 & $\begin{array}{l}\text { IFN signaling } \\
\text { transcrip- } \\
\text { tion factor }\end{array}$ & Susceptible & HSV-1 & Corneal & $\begin{array}{l}\text { Katzenell } \\
\text { et al. (2014) }\end{array}$ & STAT1 & Mycobacteria & 614892 \\
\hline & & & & & & & & $\begin{array}{l}\text { HSV-1, EBV, } \\
\text { VZV }\end{array}$ & 613796 \\
\hline & & & & & & & & Candidiasis & 614162 \\
\hline $\operatorname{Isg} 15^{-1-}$ & ISG15 & $\begin{array}{l}\text { Interferon- } \\
\text { stimulated } \\
\text { gene }\end{array}$ & Susceptible* & HSV-1 & $\begin{array}{l}\text { Intracranial/ } \\
\text { corneal }\end{array}$ & $\begin{array}{l}\text { Lenschow } \\
\text { et al. (2007) }\end{array}$ & $I S G 15$ & Mycobacteria & 147571 \\
\hline Oasl1 ${ }^{-/-}$ & OASL1 & $\begin{array}{l}\text { Interferon- } \\
\text { stimulated } \\
\text { gene }\end{array}$ & Resistant & HSV-2 & Intravaginal & $\begin{array}{r}\text { Oh et al. } \\
(2016)\end{array}$ & & & \\
\hline $\operatorname{Trp} 53^{-/-}$ & p53 & $\begin{array}{l}\text { Regulator } \\
\text { of cellular } \\
\text { stress }\end{array}$ & Resistant & HSV-1 & Intracranial & $\begin{array}{l}\text { Maruzuru } \\
\text { et al. (2016) }\end{array}$ & & & \\
\hline
\end{tabular}


Table 1 (continued)

*Incomplete penetrance of survival phenotype. These gene-deficient animals, although more susceptible than WT controls, do not all succumb to HSV infection

†Respectively, "resistant" and "susceptible" denote reduced or increased survival to HSV infection, as compared to WT control mice. "As WT" describes gene-deficient animals that are equally susceptible or resistant to HSV infection as WT controls

${ }^{\S}$ Reference to human gene deficiencies available on the Online Mendelian Inheritance in Man (OMIM) database (http://www.omim.org)

\section{Mouse experimental models of HSV infection and HSE}

HSV infections can be modeled experimentally in mice. Although humans are the principal natural reservoir for HSV, mice share several cell-surface receptors that allow for both systemic and neurotropic infection with human herpes viruses. These receptors include Nectin-1 (Pvrll) and herpes virus entry mediator HVEM (Tnfrsf14), both expressed on epithelial keratinocytes and fibroblasts (Petermann et al. 2015a, b). In addition, nectin-1 expression on neurons can facilitate the entry of HSV; intracranially infected Pvrl1 ${ }^{-/-}$mice do not develop encephalitis, and lytic viral replication in severely limited in the CNS compared to WT mice (Haarr et al. 2001; Kopp et al. 2009). While the establishment of latent HSV infection in neurons of the trigeminal ganglia (TG) is well documented in mice, the spontaneous reactivation of latent virus is difficult to measure reliably in immunocompetent hosts, but can be triggered in vivo under stress, or ex vivo in explanted TG neuron cultures (Doll and Sawtell 2017; Matundan et al. 2016; Ramakrishna et al. 2015).

Different routes of infection recapitulate different aspects of HSV pathogenesis, with some routes better suited for investigating the peripheral host response. Cutaneous inoculation of the flank, footpad, or of the oral mucosa will often limit pathology and viral replication to the site of inoculation, and involves the early recruitment of neutrophils, NK cells, and antigen-presenting cells that will migrate to secondary lymphoid organs and prime the adaptive immune response (Milora et al. 2017). More commonly, intraperitoneal or intravenous inoculations are used to model systemic HSV infection, where viral replication may occur notably in the liver (Caignard et al. 2013; Chen et al. 2016; Parker et al. 2016). Intraperitoneal and intravenous models can also result in viral invasion of the CNS and lethal encephalitis, although many studies report lethality rather than HSV titers in brain tissue or infiltration of immune cells.

Other sites of delivery better approximate the natural course of primary infection observed in human patients. Intravaginal or intranasal inoculation, or intraocular delivery by corneal scarification, can each establish productive infection in the vaginal, nasal, and corneal epithelia, respectively (Menasria et al. 2017; Reinert et al. 2012, 2016). Through the contact of the nasal epithelium and eye with the sensory termini of TG neurons, HSV virions travel by retrograde axonal transport along the TG to invade the CNS (Cook and Stevens 1973). From here, the virus is typically localized to hindbrain (brainstem, cerebellum), and can be detected in the brain ependyma and lateral ventricles (Conrady et al. 2013; Kroll et al. 2014). However, mice rarely develop the temporal or frontal lobe-localized infected lesions that are characteristic of human childhood HSV encephalitis. The olfactory bulbs can also host lytic viral replication (Menasria et al. 2017), although the virus generally avoids them altogether in intranasal models (Shivkumar et al. 2013). Alternatively, intravaginal inoculation will lead to productive infection in the dorsal root ganglia, whereupon viral particles can reach the CNS via spinal cord neurons (Wang et al. 2013). While paracellular entry is also possible in most models-as pro-inflammatory cytokines and matrix metalloproteases weaken the tight junctions of the blood-brain barrier (BBB) (Sellner et al. 2006) - HSV cannot passively invade the CNS in the event of elevated systemic HSV replication (viremia), a common invasion mechanism in many kinds of arboviral encephalitis (Salimi et al. 2016). Finally, intracranial HSV inoculation is also frequently employed in mice, a route that bypasses retrograde axonal transport and often results in disseminated CNS viral replication (Wang et al. 2012).

Additional considerations for modeling HSE include the choice of HSV strain, which have different capacities for neurovirulence and CNS invasion. For HSV-1, highly neurovirulent strains including strain 17 and McKrae, and milder strains like KOS, are often used for experimental encephalitis in mice, whereas neurovirulent HSV-2 strains often result in meningitis (Bergstrom et al. 1990; Wang et al. 2013). Higher doses usually result in more severe pathology, but can be titrated in vivo to a level where susceptible controls succumb and resistant controls survive (Caignard et al. 2013). Other non-genetic factors include the age of mice at infection, where the severity and CNS viral invasion of HSV is greater in neonate mice than in adults (Wilcox et al. 2015).

As with human HSE, host genetics play an important role in mouse susceptibility to lethal encephalitis. Inbred strains of mice have shown differential susceptibility to HSV-1 infection, with C57BL/6 mice noted for their resistance compared to other strains such as A/J, BALB/c (Lopez 1975, 1980), or 129S6SvEv/Tac (Cantin et al. 1999), which are relatively susceptible to fatal infection. Forward genetic screens have been performed to identify new susceptibility loci or genes on resistant backgrounds (Caignard et al. 2013; 


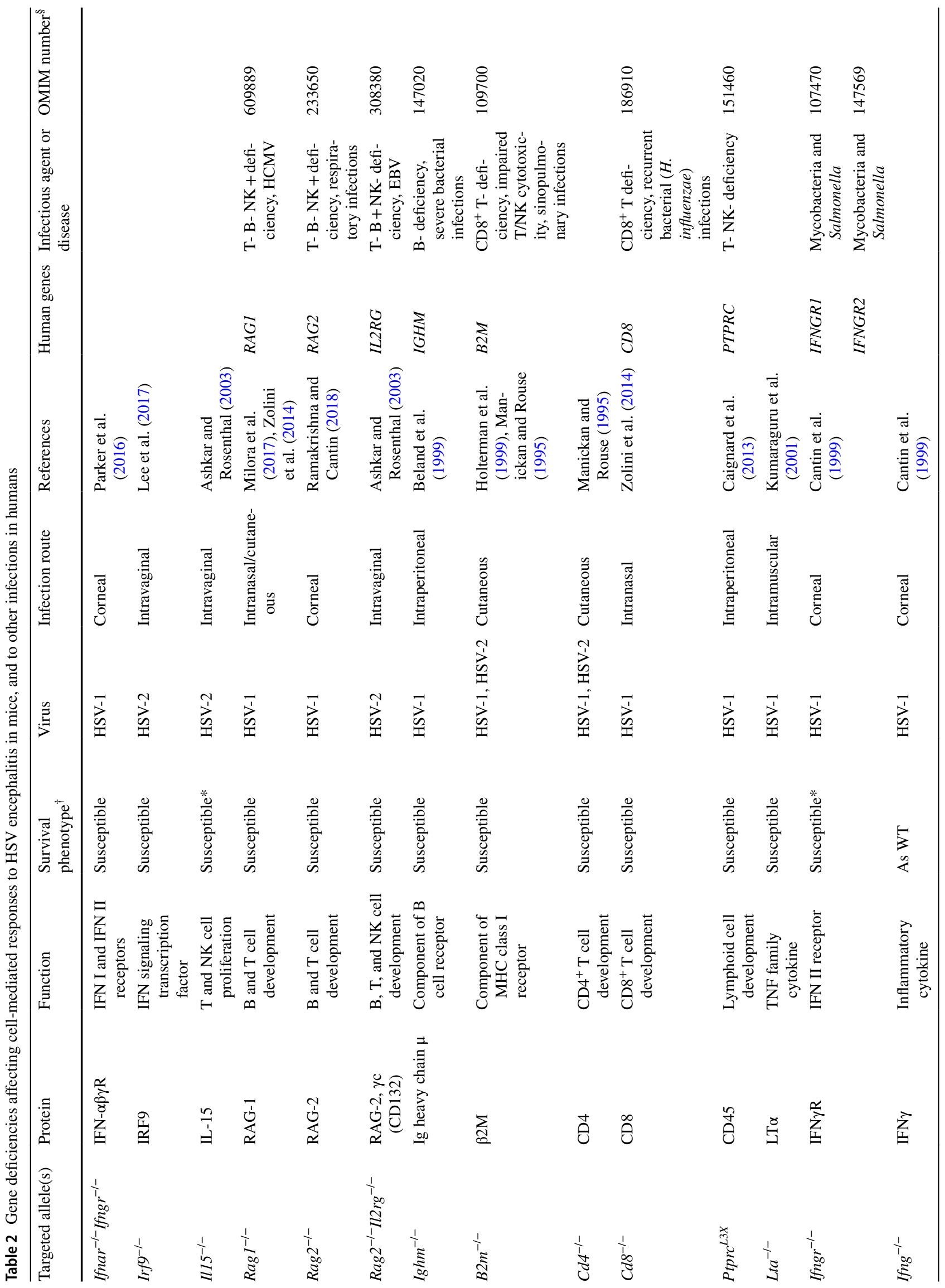




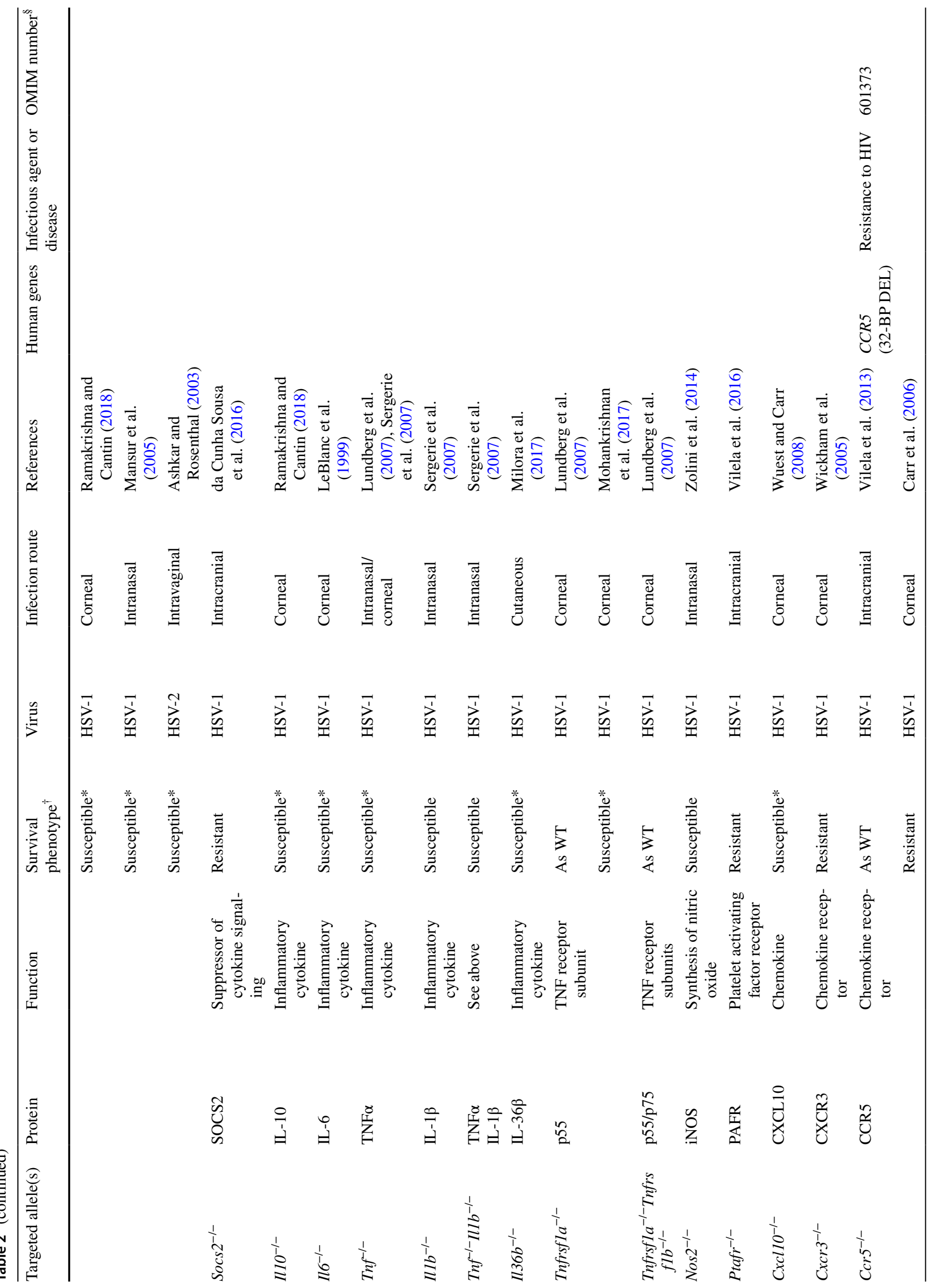


Lundberg et al. 2003; Sun et al. 2017b), and significantly more reverse genetic studies have used single-gene knockout mice, or lymphopenic mice, to inform important mechanisms of host defense. Early targeted mutagenesis studies have made extensive use of embryonic stem cells obtained from 129S6SvEv/Tac mice, which as mentioned above are relatively susceptible to HSV-1 infection (Linder 2006). Hence to control for genetic background effects in these studies, the mutant allele has been serially back-crossed to HSV-resistant C57BL/6 to generate congenic mice. However, flanking gene differences between experimental animals, and between them and their controls, can present itself as variations in the degree of susceptibility (penetrance) of the phenotype. In establishing a hierarchy in the impact of the mutations, or for comparison between different laboratories, caution must be exerted in the interpretation of the results. To better guide the reader, we have thus indicated cases in which incomplete penetrance has been observed. Here, we will focus on groups of genes that together implicate cell-intrinsic and cell-mediated mechanisms, required in the periphery, in infiltrating hematopoietic immune cells, and in resident neural cells to assure a protective response to HSV-1 infection. Ultimately, these mouse models have helped to inform the genetics of HSE pathogenesis even beyond the TLR3/IFN I axis implicated in childhood human HSE.

\section{Cell-intrinsic IFN I responses to HSV in mice}

IFN I cytokines in mice consist of 13 isoforms for IFN $\alpha$ and one for IFN $\beta$, and together ensure the control and restriction of viral replication in various cell types (Pestka et al. 2004). For DNA viruses like HSV, IFN I signaling can be initiated downstream of endosomal TLRs upon their recognition of foreign viral nucleotides (TLR3 recognizing double-stranded RNA, TLR8/7 recognizing single-stranded RNA, and TLR9 recognizing unmethylated cytosine-phosphate-guanine, or $\mathrm{CpG}$, DNA). Furthermore, cytosolic viral DNA will be sensed by the cyclic GMP-AMP synthase/stimulator or interferon genes (cGAS/STING) pathway. On the other hand, RIG-I/MDA5-mediated recognition of cytosolic doublestranded RNA appears to have a more limited role in antiHSV immunity (Liu et al. 2016; Menasria et al. 2013). IFN $\gamma$-inducible protein 16 (IFI16) is also a major viral DNA sensor in humans, with some evidence suggesting that IFI200-family genes (including Ifi204 and Ifi205) respond to IFN I or infection to fulfill a homologous role in mice (Ghosh et al. 2017; Hertel et al. 1999). The above signaling cascades converge notably on NF- $\mathrm{KB}$ and interferon regulatory factor (IRF) family transcription factors to modulate IFN I expression and other inflammatory 
cytokines. Upon binding to the IFN I receptor (IFNAR, including IFNAR1 and IFNAR2 subunits), IFN I stimulates the transcription of various interferon-stimulated genes (ISGs) that help to maintain a global antiviral program in the cell. Thus, Ifnar ${ }^{-1-}$ mice are susceptible to lethal intracranial HSV-1 (Wang et al. 2012) and to intravaginal HSV-2 (Lee et al. 2017; Reinert et al. 2012). Mouse models that are deficient for discrete factors involved in IFN I signaling have further defined the role of TLR and cGAS/STING viral nucleotide sensing in the development of HSE (Table 1; Fig. 1).

\section{TLR signaling}

Most genetic aberrations that drive HSE in children fit into the TLR3/IFN I axis, yet mice have broadened our understanding of innate viral sensing in the HSV-infected CNS to include additional TLRs. In glial cell cultures, murine astrocytes can upregulate TLR2, TLR3, and TLR4 after interacting with activated microglia, which themselves express most TLRs at steady-state and upon activation (Holm et al. 2012; Rosenberger et al. 2014). Following intravaginal HSV-2 infection, $\mathrm{Tlr} 3^{-/-}$mice are highly susceptible to HSE, and

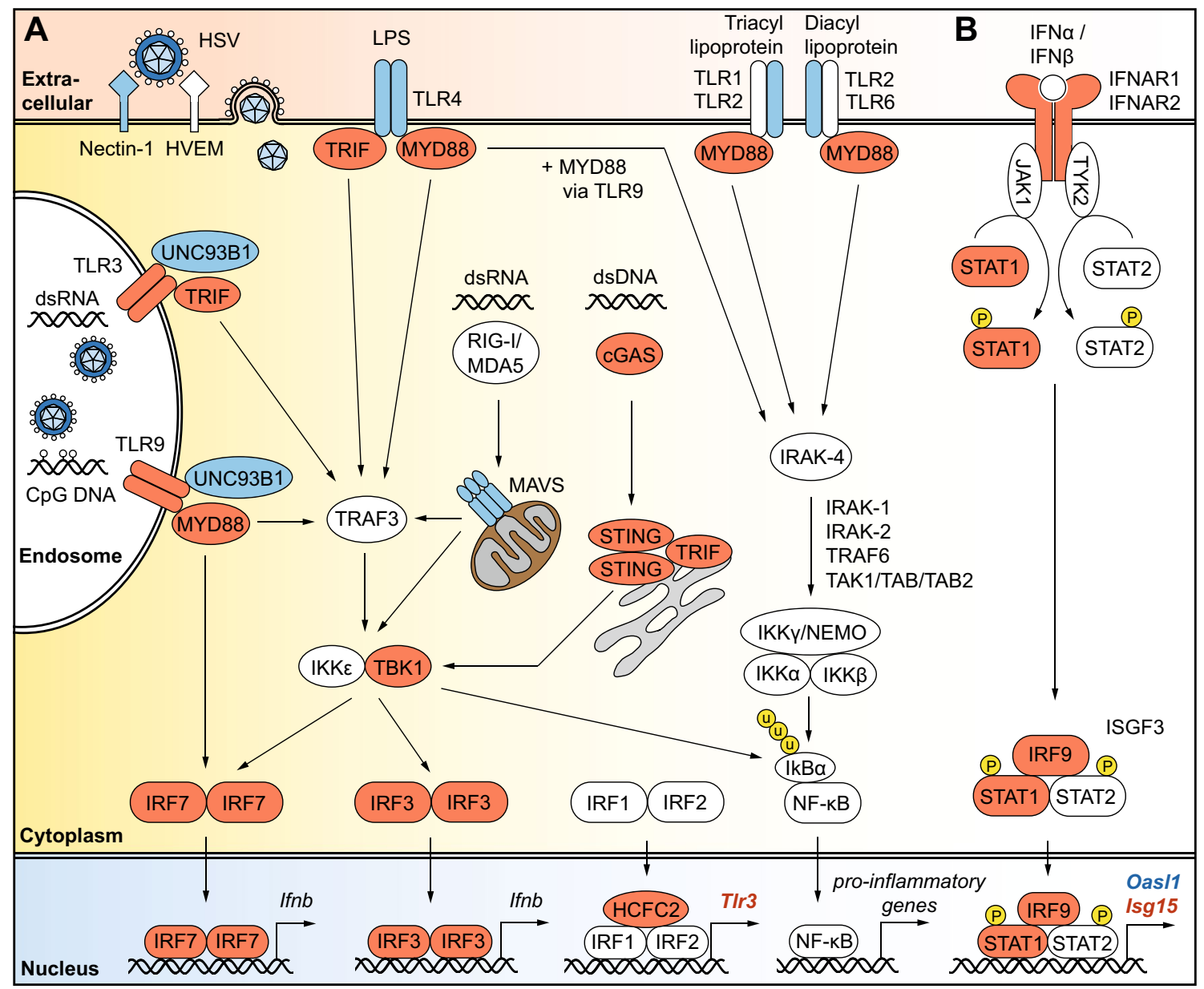

Fig. 1 Selected genetic factors and pathways essential to the cellintrinsic response to HSV encephalitis in mice. a Following infection and the entry of HSV via endosomes, or of HSV nucleocapsids into the cytoplasm, viral nucleic acids and other pathogen-associated molecular patterns are recognized by endosomal Toll-like receptors (including TLR3 and TLR9), TLR at the cell surface (including TLR1/2, TLR2/6 and TLR4), and by cytoplasmic DNA sensors cGAS/STING and RNA sensors RIG-I/MDA5. These pattern recognition receptors initiate signaling through factors including MYD88, TRIF, and TBK1 to promote the transcription of type I interferon (IFN I) and pro-inflammatory genes via transcription factors IFR3, IRF7, and NF- $\mathrm{KB}$. b The subsequent production of IFN $\alpha$ and IFN $\beta$ and engagement of the type I interferon receptor (IFNAR1/2) initi- ates JAK/STAT signaling to promote the expression of antiviral interferon-stimulated genes (ISG) that establish a protective antiviral state in the infected cell. For each reported gene defect in mice, the encoded protein is color-coded above as follows: (1) red for gene defects that lead to HSV susceptibility in at least one mouse model, (2) blue for gene-deficient mice with equal or increased resistant compared to WT control mice, and (3) white for genes that have not been tested in mice. Further gene defects identified in mice that drive susceptibility or resistance to HSV infection including the cGAS modifier TRIM14, STING cascade modifiers USP13, USP21, and iRhom2, and TBK1 modifier RNF128 are detailed in Table 1. (Color figure online) 
show increased leukocyte infiltration, viral load, and infection of astrocytes and neurons in the CNS (Reinert et al. 2012). However, while global IFN I production was unaffected in the $T l r 3^{-/-}$CNS, astrocytes from these animals failed to produce IFN $\beta$ in response to HSV-2 and were thus more readily infected ex vivo. Further, TRIF $\left(\right.$ Ticam $^{-1-}$ ) null mice, lacking the TLR3-specific intracellular adaptor TRIF, are partially susceptible to HSE, where decreased IFN $\beta$ production at day 5 post intranasal HSV- 1 infection was associated with $60 \%$ of mice developing lethal encephalitis by day 8 (Menasria et al. 2013). Thus, the murine TLR3 cascade may contribute to protective CNS IFN I production, as observed in many human childhood HSE patients.

Other TLRs, including those that depend on downstream intracellular adaptor protein MYD88, are required for protective responses to HSV. Upon intranasal HSV-1 challenge, $T l r 2^{-l-}$ mice are resistant to HSE, and $T l r 9^{-1-}$ or double $\operatorname{Tr} l 2^{-1-} \mathrm{Tl} \mathrm{O}^{-1-}$ knockout mice are partially and fully susceptible, respectively (Lima et al. 2010; Mansur et al. 2005). In this model, lesions and cellular infiltrate occur in the brain of HSE-susceptible mice. Yet, Tlr2 and Tlr 9 gene expression is mostly upregulated in the TG after infection in resistant WT mice (Zolini et al. 2014), suggesting that the TG is a crucial checkpoint for viral recognition and control. Lower levels of CCL2 have also been reported in HSE-resistant $T l r 2^{-/-}$mice, suggesting that the receptor may also play an auxiliary role in HSE pathology (KurtJones et al. 2004). However, using a more acute intracranial HSV-1 infection model to bypass the TG altogether, $\operatorname{Tr} 9^{-1-}, \operatorname{Tr} l 2^{-1-} \mathrm{Tl} r 9^{-1-}$ and adaptor Unc93b1-null mutant mice are only as susceptible as C57BL/6 mice, and each with normal IFN $\beta$ expression in the brain (Wang et al. 2012); here $T l r 2^{-1-}$ mice are significantly more resistant than WT. Similarly, Myd $88^{-/-}$mice are partially susceptible following intranasal inoculation (Mansur et al. 2005), but fully resistant to systemic HSV-1 infection (Honda et al. 2005). Overall, proper viral sensing via these MYD88-dependent TLRs is required in the TG to mount a protective innate response to CNS invasion of HSV, but may be dispensable when the virus is introduced directly in the brain parenchyma or in the periphery.

\section{cGAS/STING signaling}

Recent studies in mice have uncovered an important role for cytosolic viral DNA sensing in innate immunity to HSE. In infected mammalian cells, as HSV capsids are ubiquitinated and targeted to the proteasome for degradation, HSV genomic DNA may become available in the cytosol to bind cyclic GMP-AMP synthase (cGAS) (Horan et al. 2013). Newly produced cyclic GMP-AMP molecules can interact with and activate stimulator of interferon genes (STING), notably leading to downstream IFN I production.
Accordingly, mice lacking either cGAS or STING are highly susceptible to HSE, and are characterized by elevated viral titers in the TG, brainstem, and further dissemination into the whole brain (Reinert et al. 2016). In particular, STING is required by infected microglia cells to produce IFN I and limit viral replication (Reinert et al. 2016), but has also been implicated in autophagy pathway-mediated viral clearance following systemic and intracranial HSV-1 infection (Parker et al. 2015).

Furthermore, modifiers of cGAS and STING function contribute to HSV-1 susceptibility in single-gene or tissuespecific knockout models. First, the stability and activation of cGAS is required to initiate effective antiviral responses. IFN I-induced expression of TRIM14 favors the recruitment of USP14, a deubiquitinase which in turn promotes further IFN I expression by modifying and protecting cGAS from autophagy-mediated degradation; thus, Trim $14^{-1-}$ mice are more susceptible to infection (Chen et al. 2016). Second, deubiquitination of STING on different residues can improve or exacerbate pathology. Both Usp $13^{-1-}$ mice (Sun et al. 2017a) and myeloid cell compartment-specific Usp2 $1^{\text {flff }}$ null mice (Chen et al. 2017) are more resistant to HSV-1 infection due to heightened IFN I signaling occurring in the absence of these STING deubiquitinases. Yet, STING can also be stabilized by the site-specific removal of ubiquitin chains. As reported in $R h b d f 2^{-/-}$mice, the failed iRhom2-dependent recruitment of deubiquitinase EIFS35 and adaptor TRAF $\beta$ to the STING complex, factors that normally stabilize STING and promote its transport to the endoplasmic reticulum, results in lower serum IFN I and increased HSV-1 susceptibility (Luo et al. 2016). Finally, it has been suggested that mice lacking TRIF, previously noted for their TLR3-dependent susceptibility to intranasal HSV-1 infection (Menasria et al. 2013), may otherwise produce lower IFN I due to a deficiency in STING signaling in a susceptible model of corneal infection (Wang et al. 2016). Here, an interaction with TRIF supports the activation and dimerization of STING, lowering viral replication in ex vivo infected primary Ticam $1^{-/}$cells. Thus, TRIF is an example of a factor that bridges multiple innate sensing pathways.

\section{Transcription factors and IFN-stimulated genes}

Viral molecular pattern sensors signal through downstream transcription factors that drive the expression of IFN I and the subsequent expression of ISGs. Among these transcription factors, the nuclear translocation of active IRF3 dimers leads to early IFN $\beta$ and IRF7 expression. In turn, active IRF7 promotes elevated IFN $\alpha$, IFN $\beta$, and ISG expression. Without both transcription factors, $\operatorname{Irf} 3^{-1-} \operatorname{Irf7^{-1-}}$ mice cannot mount an antiviral response and succumb fully to corneal HSV-1 infection (Murphy et al. 2013). In this model, Irf7 contributes most to the protective response, while $\operatorname{Irf3}^{-/-}$mice are 
partially susceptible to infection. Furthermore, IRF3 phosphorylation and downstream IFN production are dependent on TBK1 kinase activity; positive regulation of TBK1 by E3 ubiquitin ligase RNF128 confers some protection to systemic HSV-1 infection in Rnf128-sufficient mice (Song et al. 2016). Additionally, other IRF-family members including IRF1 and IRF2 are known to modulate the transcription of Tlr3. In this context, mice carrying a chemically induced null mutation in $H c f c 2$, a factor that facilitates the interaction of IRF1 and IRF2 with the Tlr3 promoter, show defects in TLR3-dependent IFN production and are susceptible to retro-orbital HSV-1 infection (Sun et al. 2017b).

Signal transducer and activator of transcription 1 (STAT1) is another key transcription factor in the response downstream of IFNAR signaling. Two Statl knockout mouse models are commonly used, one with an $\mathrm{N}$-terminal deletion (Stat ${ }^{-1-} \Delta \mathrm{NTD}$ ) that disrupts active complexes of phosphorylated STAT1 with phosphorylated STAT2 (Meraz et al. 1996), and another with a deletion in the DNA-binding domain (Stat1 ${ }^{-/-} \Delta$ DBD) (Durbin et al. 1996). Although the DNA-binding domain plays a more prominent role in the mounting of an adequate response to IFN $\beta$ and control of ex vivo infection, both Stat $^{-1-}$ models are highly sensitive to corneal HSV-1 infection and succumb by day 8 post-infection (Katzenell et al. 2014). Yet, HSV-1-infected Stat $^{-1-} \triangle \mathrm{DBD}$ and $\triangle$ NTD mice distinguish themselves by their respective systemic or CNS viral tropisms (Pasieka et al. 2011b). Upon ocular infection of Stat $^{-1-} \Delta$ NTD mice that succumb to CNS-localized infection, active STAT3 and IL-6 drive inflammation in the corneal epithelium (Pasieka et al. 2009) before a heightened antiviral and pro-inflammatory response develops in the brainstem (Pasieka et al. 2011a). In these brainstems collected at the day 5 peak of HSV-1 replication, functional gene expression analysis revealed that IFN-I-dependent ISGs and IRF-family genes are upregulated in resistant 129S-background control animals; susceptible Stat $^{-/-}$mice show increased expression of inflammatory chemokines ( $\mathrm{Cxcl10}, \mathrm{Ccl} 2)$, cytokines (Ifng, Il6, Illb), markers of cell infiltration (Icaml, Il8rb), and matrix metalloproteases (Mmp3, Mmp8, Mmp9), all typical of acute HSE pathogenesis (Pasieka et al. 2011a). Thus, STAT1-dependent IFN I signaling is pivotal for the initiation of a protective innate antiviral response to HSV-1 in the mouse CNS.

Certain ISGs have also been found to contribute to a protective antiviral response to HSV infection in mice. Notably, the lack of ISG15-an IFN I-induced ubiquitin-like factor that modifies several protein targets that help to establish an antiviral state in infected cells-renders mice more sensitive to lethal HSV-1 following intracranial and intraocular infections (Lenschow et al. 2007). On the other hand, negative regulators of IFN I, including IRF7 antagonist OASL1, can exacerbate viral pathogenesis; Oasl $^{-/-}$mice are partially protected from lethal HSV-2 infection (Oh et al. 2016). Thus, genetic defects that target IFN I-responsive proteins, as well as components of viral pattern recognition pathways and their downstream transcription factor-dependent signaling, modify the innate capacity of mouse cells to reduce HSV-1 viral replication, and to ultimately clear the infection in vivo.

\section{Cell-mediated responses to HSV infection in mice}

In the context of neurotropic viral infection, immune cell populations contribute both to inflammation and to the recognition and targeted killing of infected cells. Spurred on by the production of antiviral factors, the protective cellular response to HSV-1 in mice progresses through three general phases. First, in the periphery, natural killer cells (NK), myeloid cells, and various dendritic cell (DC) subsets will produce IFN I, IFN $\gamma$, and other pro-inflammatory cytokines necessary for the further activation and proliferation of NK cells (Kassim et al. 2006; Swiecki et al. 2013). Antigenpresenting cells including DCs will migrate to the secondary lymphoid organs to expose $\mathrm{B}$ cells, $\mathrm{CD} 4^{+}$and $\mathrm{CD} 8^{+} \mathrm{T}$ cells to viral antigen. Next, these activated cytokine-producing lymphocytes and myeloid cells can invade the CNS by the lymphatics network or directly across an inflammationweakened BBB. Ultimately, alongside activated glial cells, the CNS infiltration of immune cell can either benefit the host by eliminating infected cells and reducing viral titers, or drive overwhelming inflammation characteristic of HSE pathology. Mouse models have been especially useful to dissect the role of discrete genes in these three aspects of cellmediated HSV-1 immunity (Table 2; Fig. 2).

\section{Peripheral lymphoid and myeloid cell responses}

Innate IFN production plays a fundamental role in the activation of the cellular immune response to early HSV-1 replication. Infected Ifnar ${ }^{-1-}$ Ifngr ${ }^{-/-}$mice, lacking both type I and II IFN receptors, exhibit high viral loads in the liver due to a failure of the IFN signaling-deficient hematopoietic compartment to control the infection (Parker et al. 2016). For example, HSV-2 replication at the vaginal mucosa is controlled by the IFN I-dependent recruitment of cytotoxic Granzyme $\mathrm{B}^{+} / \mathrm{IFN} \gamma^{+} \mathrm{NK}$ cells and CCL2-producing Ly6 $\mathrm{C}^{\mathrm{HI}}$ inflammatory monocytes; Ifnar ${ }^{-/-}$mice recruit only CXCL1/ CXCL2-producing Ly6C ${ }^{\mathrm{LOW}}$ monocytes that instead promote neutrophil invasion, and fail to initiate a protective antiviral response (Uyangaa et al. 2015). In a similar model, Ifnar $^{-/-}$and $I r f 9^{-/-}$mice are both more sensitive to lethal HSV-2 infection, where few IL-18-producing inflammatory monocytes are recruited to the vaginal mucosa, resulting in low IL-18-dependent production of IFN $\gamma$ in NK cells (Lee 


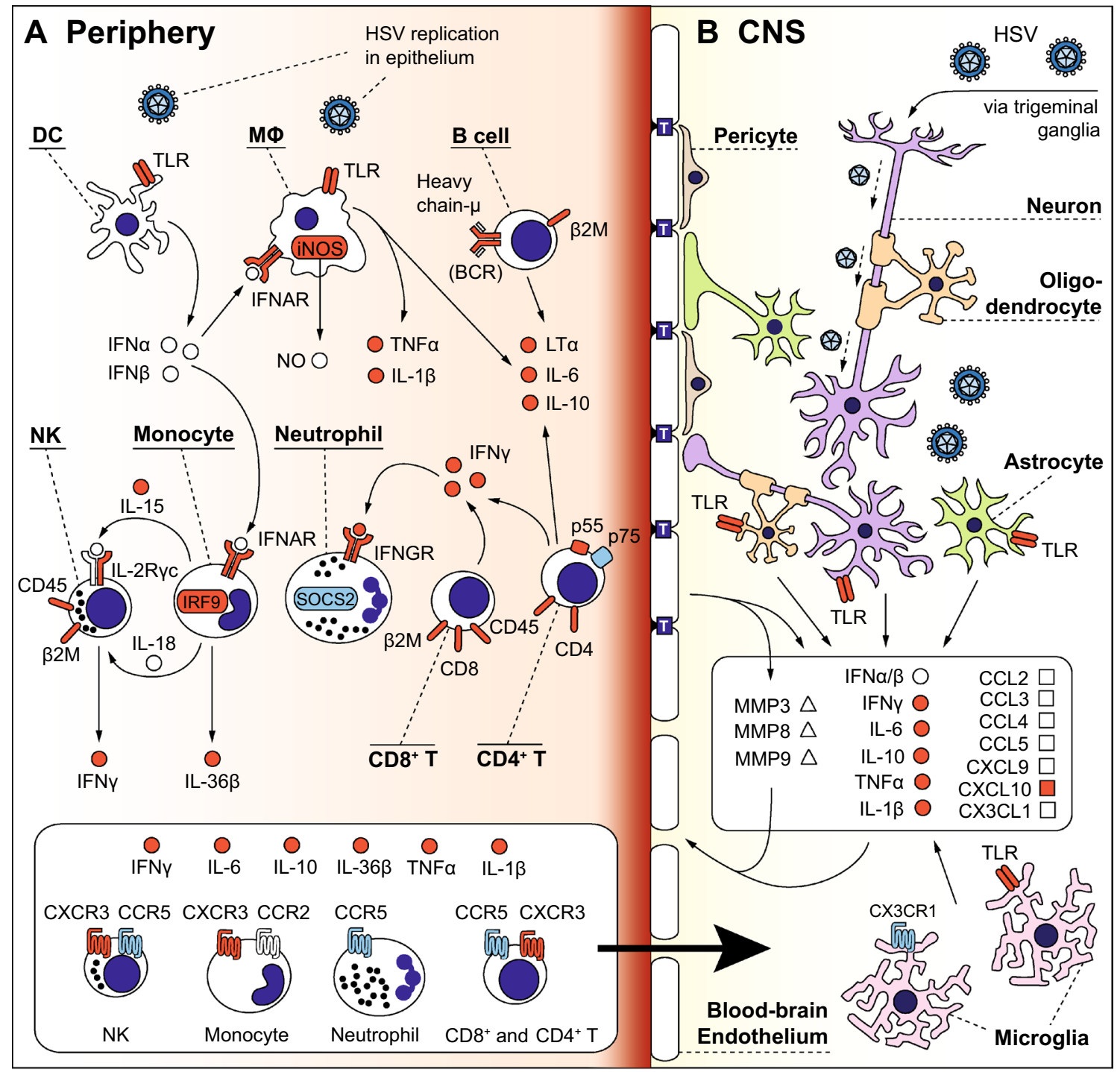

Fig. 2 Selected genetic factors and pathways essential to the cellmediated immune response to HSV encephalitis in mice. a HSV will first infect and replicate in epithelial cells and keratinocytes, activating chemokine pathways and triggering dendritic cells (DC) to produce type I interferon (IFN I). Responding to IFN I, macrophages $(\mathrm{M} \Phi)$ and monocytes will produce inflammatory cytokines (TNF $\alpha$, IL-1 $\beta$ ), and contribute to the activation of cytotoxic IFN $\gamma$-producing natural killer cells (NK). Furthermore, activated B cells, and especially effector $\mathrm{CD} 4^{+} \mathrm{T}$ cells and cytotoxic $\mathrm{CD} 8^{+} \mathrm{T}$ cells, will help to maintain an adequate antiviral response including $\mathrm{T}$ cell-dependent production of cytokines like IFN $\gamma$, which will promote neutrophil expansion. While single-gene defects in factors including CD45, $\beta 2 \mathrm{M}$, Heavy chain- $\mu, \mathrm{LT} \alpha, \mathrm{CD} 4, \mathrm{CD} 8, \mathrm{RAG}-1, \mathrm{RAG}-2$, and IL-2R $\gamma \mathrm{c}$ have all been implicated in susceptibility to HSV encephalitis in mice, it remains unclear whether their essential function in immune cell development, or any specific effector functions, strictly drives susceptibility to infection. b In the CNS, the principal route of entry of HSV is via the axons of the trigeminal ganglia. HSV readily infects neurons, as well as glia including oligodendrocytes, astrocytes, and microglia. The TLR-dependent recognition of HSV by glia and neu- rons may drive expression of cytokines including IFN I, IFN $\gamma$, IL-6, $\mathrm{TNF} \alpha$, and IL-1 $\beta$. Along with matrix metalloproteases (MMP3, 8, 9), these CNS cytokines and those produced in the periphery may disrupt the blood-brain barrier (BBB) by weakening the tight junctions (marked above by "T"-labeled blue squares) between BBB endothelial cells. Finally, the expression of various chemokines by CNS-resident cells will attract immune cells with cognate chemokine receptors (CCR2/CCL2; CCR5/CCL3, CCL4, CCL5; CXCR3/CXCL9, CXCL10; CX3CR1/CX3CL1) across the permeable BBB into the CNS (marked by the black arrow between panels $\mathbf{a}$ and $\mathbf{b}$ ). In the CNS, these infiltrating immune cells may enhance virus clearance, but also contribute to HSE pathology. The pathways shown above have been directly involved in mouse HSE studies, but do not reflect the full production of factors by all immune, neuronal, and glial cells, or their complete downstream effects. For each reported gene defect in mice, the encoded protein is color-coded above as follows: (1) red for gene defects that lead to HSV susceptibility in at least one mouse model, (2) blue for gene-deficient mice with equal or increased resistant compared to WT control mice, and (3) white for genes that have not been tested in mice. (Color figure online) 
et al. 2017). Lower levels of IFN $\gamma$ are also implicated in an HSV-2-susceptible $1115^{-/-}$model (Ashkar and Rosenthal 2003). As for the role of cytotoxic NK cells in the infected CNS, a forward genetics approach identified a locus on murine chromosome 6 that may underlie resistance to HSE in C57BL/6 mice (Kastrukoff et al. 2015). Susceptible BALB/c background mice, or NK-depleted C57BL/6 mice, exhibited viral spread to the cerebellum and augmented titers in the brainstem. Thus, NK-specific genes in this resistance locus, including $C d 94$, the Ly49 cluster, and NKG2 cluster, may contribute to the protective antiviral response to HSE.

Classical adaptive immune cells are also important in the control of acute HSV infection and the development of HSE in mice. Both $\mathrm{Rag}^{-/-}$(lacking mature B and T cells) and $\mathrm{Rag}^{-/-} \mathrm{Il}_{2 \mathrm{rg}^{-/-}}$mice (lacking mature B, T, and NK cells) are fully susceptible to lethal intranasal HSV-1 or intravaginal HSV-2 infection, respectively (Ashkar and Rosenthal 2003; Zolini et al. 2014). Furthermore, B cell $\left(\mathrm{Ighm}^{-/-}\right)$- , MHC I $\left(B 2 \mathrm{~m}^{--}\right)-$, and T cell $\left(C d 4^{--}\right.$and $\left.C d 8^{-/-}\right)$-deficient animals are all more susceptible than WT mice in different models of HSV infection and HSE (Beland et al. 1999; Holterman et al. 1999; Manickan and Rouse 1995; Zolini et al. 2014). As with other viral infections, effector CD4 ${ }^{+}$ $\mathrm{T}$ cells and cytotoxic $\mathrm{CD} 8^{+} \mathrm{T}$ cells play a major role in the elimination of replicating virus. A loss-of-function mutation in CD45 $\left(\right.$ Ptprc $\left.^{L 3 X}\right)$, identified in a chemical mutagenesis screen for HSV-1 susceptibility in mice, results in a lack of T and NK cells that drives susceptibility to HSE (Caignard et al. 2013). Here, $\mathrm{CD} 8^{+} \mathrm{T}$ cells, supported by IFN $\gamma-$ producing $\mathrm{CD}^{+}{ }^{+} \mathrm{T}$ effector cells, are required for effective viral clearance in the CNS. In response to infection, $\mathrm{CD} 4^{+}$ T cell-specific Stat $^{-/-}$mice have increased HSV-1-specific $\mathrm{CD}^{+}{ }^{+} \mathrm{T}$ cells that express lower levels of KLRG- 1 and IFN $\gamma$, suggesting that antiviral $\mathrm{CD}^{+} \mathrm{T}$ cell function relies in part on their cooperation with STAT3-competent $\mathrm{CD}^{+}$cells (Yu et al. 2013). In addition, $\mathrm{CD} 8^{+} \mathrm{T}$ cell expression of Dok-1 and Dok-2 proteins, that each function in proliferation, activation, and migration of hematopoietic cells, has been shown to support and amplify HSV-1-specific CD8 ${ }^{+}$ effector responses; the absence of Dok1 and Dok2 does not, however, impact viral titers in the cornea or TG during primary infection (Lahmidi et al. 2017). Other $\mathrm{CD}^{+} \mathrm{T}$ cell defects have also been found to increase susceptibility, notably in lymphotoxin- $\alpha$-deficient $\left(\mathrm{Lta}^{-/-}\right)$mice that, without adequate cytotoxic IFN $\gamma^{+} \mathrm{CD} 8^{+} \mathrm{T}$ cell responses, succumbed to lethal intramuscular HSV-1 infection (Kumaraguru et al. 2001).

\section{Pro-inflammatory cytokines and immune cell invasion}

The contribution of the immune system to HSE resistance is further supported by findings that single cytokine gene-knockout models are highly susceptible to infection. While the elevated and concerted expression of pro-inflammatory cytokines is a hallmark of pathological inflammation, individual cytokines are essential and non-redundant in a protective response. At high doses of corneal HSV-1, IFN $\gamma$ receptor-null $\left(\right.$ Ifngr $\left.^{-/-}\right)$mice are more susceptible to HSE than both Ifng ${ }^{-1-}$ and WT mice (Cantin et al. 1999). Yet, Ifng $^{-1-}$ mice are partially susceptible to HSV-1 and HSV-2 infection (Ashkar and Rosenthal 2003; Mansur et al. 2005), and approximately $75 \%$ of mice succumb to lower doses of corneal HSV-1 between days 10 to 16 post-infection, despite controlling virus as well as resistant WT mice by day 8 (Ramakrishna and Cantin 2018). This may suggest that IFNy plays a role in limiting cell infiltration and inflammation, rather than as a direct antiviral mechanism (Ramakrishna and Cantin 2018). Yet in the context of HSV-1 infection, the proliferative and cytotoxic capacities of NK cells and of effector $\mathrm{CD}^{+}$and $\mathrm{CD} 8^{+} \mathrm{T}$ cells also rely on IFN $\gamma$ expression to clear HSV-1-infected cells and reduce viral load in the CNS (Caignard et al. 2013).

Furthermore, susceptible Ifng $^{-/-}$mice express elevated levels of granulocyte colony stimulating factor (G-CSF), promoting the excessive CNS recruitment of degranulating neutrophils (Ramakrishna and Cantin 2018). G-CSF also induces the expression of suppressor of cytokine signaling 2 (SOCS2). Validating this pathway, either depletion of G-CSF in Ifng ${ }^{-/-}$mice (Ramakrishna and Cantin 2018) or ablation of SOCS2 (Socs $2^{-/-}$mice) (da Cunha Sousa et al. 2016), lowered neutrophil infiltration and thus increased HSE resistance. As for the repressive function of IL-10, $I l 10^{-/-}$mice are highly susceptible to lethal HSE (Ramakrishna and Cantin 2018). IL-6, which is known to be overexpressed in the CNS at the peak of HSE, also confers protection to HSE in IL-6-competent mice compared to $I l 6^{-/-}$mice (LeBlanc et al. 1999).

Tumor necrosis factor (TNF $\alpha)$ is another example of a key pro-inflammatory cytokine that is involved in neuroinflammation, and yet also acts to control infection and prevent encephalitis. $\mathrm{Tnf}^{-1-}$ mice are susceptible to HSE, where HSV-1 disseminates past the brainstem and cerebellum (Lundberg et al. 2007; Sergerie et al. 2007). $T n f^{-1-}$ mice share a similar susceptibility profile with $I l l b^{-1-}$ and $T n f^{-1-} I l l b^{-/-}$double-knockout mice, which lack pro-inflammatory IL-1 $\beta$ processed downstream of the inflammasome complex and capable of activating lymphocytes and inducing IFN I and II production (Sergerie et al. 2007). IL-1-family cytokine IL-36 $\beta$ (Il36b gene) is also involved in protective immunity to lethal HSE (Milora et al. 2017). As with circulating immune cells, TNF $\alpha$ is produced by resident microglia in the brain; its cognate receptors $\mathrm{p} 55$ (Tnfrsfla) and p75 (Tnfrsflb), expressed on infiltrating and resident immune cells, play a more complex role in HSV immunity. One study found that a 3200 plaque-forming units 
(PFU) HSV-1 corneal infection of Tnfrsfla ${ }^{-/-}$mice resulted in self-resolving viral replication in the brainstem and TG. WT and Tnfrsfl $1 a^{-/-}$Tnfrs $f 1 b^{-1-}$ double-knockout mice were also resistant to HSE (Lundberg et al. 2007). In another study, Tnfrsfla $a^{-1-}$ mice were only slightly more sensitive at a higher dose $\left(10^{5} \mathrm{PFU}\right)$ of corneal HSV-1 than WT mice (Mohankrishnan et al. 2017). Together, these studies suggest that a protective response to HSE depends on TNF $\alpha$ and not its receptors, or otherwise partly relies on p55-mediated inflammation and cytokine production in certain models of acute disease. A final cytokine that contributes to resistance is inducible nitric oxide synthase (iNOS; Nos2 gene), produced chiefly by myeloid cells. iNOS-deficient mice exhibit poor virus control following footpad HSV-1 infection (MacLean et al. 1998), and 100\% mortality to intranasal infection and an overall increase in pro-inflammatory factors TNF $\alpha$, CCL2, Rantes and CXCL10 in the TG characteristic of HSE (Zolini et al. 2014).

While protective cellular responses depend on the above cytokines, their elevated expression can compromise the integrity of the BBB and allow cells to infiltrate and further damage the infected CNS. In mouse models of neurotropic infection, the infiltration of immune cells is enabled by $\mathrm{TNF} \alpha$ and IL-6, and various matrix metalloproteases are known to reduce the expression of endothelial and tight junction proteins at the barrier (Ashley et al. 2017; Li et al. 2015; Rochfort et al. 2016). CNS lymphatics can also facilitate infiltration (Louveau et al. 2015). Following HSV infection, the further development of blood and lymph vessels has been studied in the context of the cornea. TNF $\alpha$ accelerates HSV-1-driven lymphangiogenesis in the corneal epithelium, as does IL-6 in the absence of TNF $\alpha$ (Bryant-Hudson et al. 2014). Here, viral ICP4 transcripts act as enhancers of vascular endothelial growth factor A (VEGF-A) expression to increases vascularization and HSV-1-specific antiviral $\mathrm{CD}^{+} \mathrm{T}$ cells in the cornea and TG (Gurung et al. 2017). The role of lymphangiogenesis is less clear in the brain of HSE-susceptible mice. However, both vascular permeability and lymphoid or myeloid cell CNS infiltration is reduced in platelet activating factor receptor-deficient $\left(\mathrm{Ptafr}^{-1-}\right)$ mice, resulting in delayed mortality upon intracranial HSV-1 (Vilela et al. 2016).

\section{CNS-infiltrating immune cells and microglial activation}

In the infected CNS, once thought to be off-limits to the immune system, the activation of resident cells and the infiltration of immune cells can either restrict viral replication to limit inflammation, or contribute directly to lethal encephalitis. Trafficking lymphocytes can be detected as early as day 5 post-HSV-1 infection in the TG, where TLR2- and TLR9dependent pathways drive the production of granzyme $\mathrm{B}$ and perforin by cytotoxic NK and $\mathrm{CD} 8^{+} \mathrm{T}$ cells, of iNOS by macrophages, and of IL- $1 \beta$ by conventional DCs (Lucinda et al. 2017). The infected TG are also noted for their high expression of CCL2 in susceptible $\mathrm{Tlr} 2^{-/-} \mathrm{Tlr} \mathrm{O}^{-/-}$mice, which leads to further recruitment of monocytes and $\mathrm{T}$ cells to the CNS. In addition, infiltrating neutrophils and F4/80 macrophages are known to contribute directly to HSE pathology in susceptible 129 background mice (Lundberg et al. 2008).

CXC-motif chemokines secreted by resident glial cells, blood-brain endothelial cells, or hematopoietic cells help to recruit inflammatory cells that express cognate chemokine receptors. CXCL10 expression is sharply upregulated upon infection and, like fellow chemokine CXCL9, binds receptor CXCR 3 expressed on monocytes, NK cells, and T cells to promote their homing to the site of infection. Thus, $\mathrm{CxcllO}^{-/-}$mice are more sensitive to lethal HSE than WT mice, and fail to control viral replication in the brain stem due to low recruitment of $\mathrm{NK}$ and $\mathrm{CD}^{+} \mathrm{T}$ cells (Wuest and Carr 2008). CXCL10 is also implicated the protective response to HSV-1-related pathology in the cornea, and in the absence of CXCL10, CXCL9 may play a compensatory role to limit herpes keratitis (Tajfirouz et al. 2017). Moreover, bone marrow chimeric mouse models have been very useful to limit monogenic defects in chemokine signaling to either the hematopoietic or tissue-resident cell compartments. The HSE-protective effect of CXCL10 is dependent on bone-marrow-derived cells that home to the CNS, and not on radio-resistant microglia or stromal cells of the CNS (Wuest et al. 2011). For example, it has been proposed that $\mathrm{CXCR}^{+}$NK cells, for which CXCL10 is thought to be the principle attractant, may be important effectors of the antiviral response in Cxcl10-competent mice (Wuest and Carr 2008).

Although CXCL10 has a non-redundant protective role in the CNS, mice that lack its receptor CXCR3 $\left(\mathrm{Cxcr}^{-/-}\right)$ are resistant to HSV-1 infection, and slightly more resistant than WT C57BL/6 mice (Wickham et al. 2005; Zimmermann et al. 2017), suggesting that some $\mathrm{CXCR} 3^{+}$immune cells may be the cause of lethal inflammation. Consistent with their survival, $\mathrm{Cxcr} 3^{-1-}$ mice maintain control of viral replication in the brain ependyma and hippocampus by relying on intact IFN $\beta$ signaling (Kroll et al. 2014; Zimmermann et al. 2017). However, low cytokine (TNF $\alpha$, IFN $\gamma$ ) and chemokine (CXCL9, CXCL10, CCL2) expression in resistant animals limits leukocyte infiltration (Zimmermann et al. 2017). CXCR3-deficiency also completely excludes activated $\mathrm{CD} 8^{+} \mathrm{T}$ cells from the CNS, cells that otherwise upregulate CXCR3 in WT hosts. Thus, the infiltration of $\mathrm{CXCR}^{+}$monocytes and $\mathrm{T}$ cells from the periphery drives HSE pathology in mice (Menasria et al. 2015; Zimmermann et al. 2017). 
Of note, other models of defective chemokine receptor signaling show altered recruitment of immune cells to the CNS without necessarily affecting survival or outcome. For example, $\mathrm{Crr} 5^{-1-}$ and WT mice are both completely susceptible to intracranial HSV-1, yet knockouts display increased neutrophil homing to the CNS (Vilela et al. 2013). Alternatively, $\mathrm{Crr} 5^{-/-}$mice feature higher numbers of $\mathrm{T}$ cells in the TG, but are only slightly more resistant to corneal HSV-1 infection compared to WT (Carr et al. 2006). CCR5 receptor is expressed on most immune cells, neurons, and glial cells, and engages many chemokines including CCL3 (MIP-1 $\alpha$ ), CCL4 (MIP-1 $\beta$ ), and CCL5 (RANTES); the expressions of these and other chemokines are all increased in $C \mathrm{cr} 5^{-/-}$mice in both infection models, hinting at an intricate compensatory mechanism. Thus, while the role of individual chemokine signaling pathways in protective or detrimental host responses is complex and not fully understood, the excessive infiltration of cytotoxic and inflammatory cells to the CNS is most often auxiliary to HSE pathogenesis.

Finally, CNS-resident microglia can play an important role in the development of HSE, especially in the context of innate antiviral immunity. Abundant macrophage-like glial cells, microglia are activated in the HSV-1-infected brain and can produce a number of chemokines and cytokines including IFN I that can help control viral replication, or in the long-term promote HSE pathology (Conrady et al. 2013; Marques et al. 2008; Wuest and Carr 2008). Expression of CX3CR1 on microglia, which recognizes inhibitory CX3CL1 produced by healthy CNS cells, helps maintain a protective, anti-inflammatory environment in the brain. Therefore, $C x 3 c r l$-deficiency in the radio-resistant compartment of chimeric mice is sufficient to render them susceptible to lethal intranasal HSV-1 infection (Menasria et al. 2017). Here, $C x 3 \mathrm{Cr}^{-1-}$ microglia fail to contain HSV-1 spread in the CNS, which recruits elevated numbers of neutrophils and inflammatory monocytes to the site of infection. Furthermore, the ablation of CD118 (IFNAR1) in radioresistant microglia has been shown to drive HSV-1 viral load in the CNS, implicating TRIF-dependent production of IFN I by microglia in the protective response to HSE (Conrady et al. 2013). Ultimately, microglia are required for proper IFN I-mediated control of HSV-1 in infected neurons and glial cells of the CNS, and to avoid a general shift towards lytic cell death and neuroinflammation that underlie HSE.

\section{Cell death and autophagy in mouse HSE pathology}

Recent studies have also relied on mouse models and primary cells to investigate cell death pathways and their role in the pathology of the infected CNS. In the brain, homeostasis is maintained by patrolling microglia that detect pathogens and damage signals, while the more numerous astrocytes promote neuronal survival. In primary murine cultures, HSV-1 infects both these glial cell types, and both secrete pro-inflammatory factors and IFN I (Aravalli et al. 2005). Virus replication is controlled and self-limited in microglia that preferentially undergo early caspase 3 - and TNF-dependent apoptosis; infected astrocytes yield higher viral titers and die at later time-points from Fas-dependent apoptosis (Aravalli et al. 2006).

In the context of the CNS, apoptotic cell death can function as a cell-intrinsic antiviral mechanism by depriving the virus of host cells within which to replicate, but can also be a consequence of infection that drives pathology and inflammation. For example, cells lacking $\mathrm{X}$-box binding protein 1 $\left(\mathrm{Xpb}^{-1-}\right)$, a key player in the unfolded protein response that relieves stress at the endoplasmic reticulum, are unable to initiate apoptosis upon HSV-1 infection, resulting in more elevated viral titers (Fink et al. 2017). More generally, various cellular stress responses, including infection, can signal through p53 to promote cell death and apoptosis. Following in vitro $\mathrm{HSV}-1$ infection, $\mathrm{p} 53$ can enhance or depress the expression of viral proteins ICP22 and ICP0, respectively, to modulate viral replication in a human epithelial cell line (Maruzuru et al. 2013). In vivo, p53-null (Trp53--) mice are significantly more resistant to intracranial HSV-1 infection than susceptible WT mice (Maruzuru et al. 2016). Further, the p53-deficient CNS exhibits no important cell death or HSE pathology, and reduced infiltration of immune cells, suggesting that virus is controlled independently of cell death; p53-dependent gene signatures are associated with HSE in susceptible Trp $53^{+/+}$control mice. Thus, apoptosis of infected glial cells, and likely including infected neurons, appears to be detrimental and central to HSE pathogenesis in mice.

Neurons are especially vulnerable to acute neurotropic viral infections. Damage caused by lytic neuronal cell death can have severe impact on the host. Consequently, neurons respond very differently from glial cells to IFN I signals, and aim to avoid IFN I-induced apoptosis. Upon infection in vivo, neuron-specific STAT1-deficiency (Stat ${ }^{N-/-}$ ) leads to high viral titers in the TG and brain stem and the development of HSE (Rosato et al. 2016). Murine neurons also do not upregulate apoptosis in response to IFN unlike fibroblasts (Rosato et al. 2016; Yordy et al. 2012). Rather, STAT1-dependent IFN $\beta$ signaling only managed to restrict the replication of a mutant $\Delta \gamma 34.5 \mathrm{HSV}-1$ virus lacking viral protein ICP34.5 (Rosato and Leib 2014). While ICP34.5 expression is known to reduce the activity of host IFN I (Manivanh et al. 2017), these data also support a role for IFN I signaling in initiating antiviral mechanisms alternate to apoptosis, namely, IFN I-induced autophagy.

Viral ICP34.5 has been extensively studied in the context of its Beclin-binding domain, which can interact with 
Beclin 1 to prevent autophagy in infected neurons (Orvedahl et al. 2007). Thus, neurotropic HSV viruses are equipped to counter autophagy, a well-established recycling mechanism that is preferentially induced in neurons to reduce viral replication while avoiding pathological cell death and ensuring survival (Yakoub and Shukla 2015). Neurons lacking key autophagy factor ATG5 $\left(\operatorname{Atg} 5^{-/}\right)$yield higher viral titers in culture, following infection with both a Beclin-binding domain-deficient and functional HSV-1 virus, suggesting that while ICP34.5 certainly reduces autophagy, autophagy can also be initiated at early time-points before ICP34.5 is expressed to help reduce viral load (Yordy et al. 2012). Alternatively, Sting ${ }^{-1}$ mice are also susceptible to intracranial and corneal infection with Beclin-binding domaindeficient HSV-1 compared to resistant control mice, highlighting the role of STING-dependent autophagy in in vivo antiviral control (Parker et al. 2015). Finally, if not to induce apoptotic cell death or traditional antiviral responses, IFN I does induce the formation of unique autophagosome clusters in treated neurons that are absent in IFN signaling-deficient cells $\left(\right.$ Irf3 $^{-/-}$, Ifnar ${ }^{-/}$Ifngr $^{-/-}$, Stat $\left.^{-/-}\right)($Katzenell and Leib 2016). As autophagy is less impeded in infections with Beclin-binding domain-deficient HSV-1, the mutant virus also spreads differently in the BALB/c brain, where increased autophagy and NLRP3-dependent inflammasome activation correlated with a reduction in viral burden in the brain and lower HSE incidence (Zhang et al. 2013a). Thus, these data suggest that neurons can rely on the IFN I/autophagy axis to control viral replication without resorting to apoptotic cells death, but the efficient blocking of these pathways by viral proteins further complicates our understanding of HSE development in vivo.

\section{Perspectives}

Altogether, mouse models have refined our understanding of HSV infection and invasion of the CNS. Reverse genetic approaches have not only confirmed several childhood HSE-protective genes (Tlr3, Trif, Stat1), or revealed others belonging to overarching TLR pathways (Myd88, Irf3, Irf7, $\operatorname{Tl} 9$ ), but have also implicated many innate and adaptive immunity genes that better define mechanisms underlying HSE. Further, genetic mouse models that are differentially susceptible, based on the route of viral entry to the CNS, highlight the importance of early antiviral control by different viral pattern recognition mechanisms at mucosal surfaces, in the TG or in the CNS proper. Accordingly, antiviral treatment with acyclovir is the first-line treatment for HSE in humans, and works in mice to improve survival (Long et al. 2011; Quenelle et al. 2018). IFN $\alpha$ is also capable of limiting HSV infection in human neuronal culture (Pourchet et al. 2017), and is sometimes used in combination therapy to treat other viral infection (Sagnelli et al. 2017). Treatment of mice with cyclic dinucleotide agonists of the cGAS/STING pathway protected animals from HSV-2 replication, while TLR agonist treatment in mice also limited HSE development (Boivin et al. 2008; Skouboe et al. 2018); topical TLR7 agonist imiquimod has been shown to be ineffective in human HSV-2-infected patients (Schacker et al. 2002). In mice under the Tlr3-independent IFN I pathway, drug-targetable genes might also include deubiquitinases (TRIM14, USP13, USP21, iRhom2) that modify factors in the cGAS/STING cascade to effect IFN I production and HSE outcome.

These mouse studies have also highlighted an important contribution of trafficking and infiltrating immune cells to HSE pathogenesis. For example, peripheral and CNS-invading NK cells are involved in several gene-knockout models (Irf9, Ifng, Ifngr, Il15, Cxcl10); the protective antiviral function of NK cells in murine HSE may warrant further study into using NK cells as a targeted antiviral therapy. In general, cytokines appear to be protective in mouse HSE, despite being involved in late-stage neuroinflammation. Chemokine dynamics play complex roles in limiting or promoting CNS invasion, or even activating resident glial cells. Understanding the balance between inflammation and cell death in the CNS might help to reduce the risk of long-term sequelae that may develop in many cases of acyclovir-treated encephalitis.

Furthermore, these aspects of mouse HSE might help inform mechanisms that underlie different types of viral encephalitis in humans, which are challenging to model appropriately in mice. While neonate and adult mice react differently to CNS infection, current mouse models do not capture the individual variation in human HSE pathologies, which may depend on the neurovirulence of the viral strain, on the primary site of infection, or on the reactivation of HSV from latency in sensory neurons. Other types of encephalitis, including autoimmune anti-NMDAR (N-methyl-D-aspartate receptor) encephalitis, have been reported in older adults that have recovered from HSE earlier in life, but later develop neuroinflammation due to antiNMDAR antibodies in the cerebrospinal fluid that may stem for exposure to HSV antigens (Armangue et al. 2014; Omae et al. 2018). Viral escape from latency can also be triggered by certain drugs, most strikingly by natalizumab, approved for treatment of relapsing-remitting multiple sclerosis and Crohn's disease, which has been reported to drive John Cunningham virus (JCV) reactivation from latency in the brain and lead to progressive multifocal leukoencephalopathy in some patients (Bloomgren et al. 2012).

Cases of HSE worldwide are usually reported at 2 to 4 per million individuals per year (Jorgensen et al. 2017). While HSV-1 and HSV-2 prevalence are decreasing in the United States (McQuillan et al. 2018), the ubiquity of these viruses has prompted many studies on the involvement of herpes 
viruses in complex CNS neurodegenerative or chronic inflammatory diseases. Most notably, HSV-1 infection has been linked to Alzheimer's disease and to the expression of the apolipoprotein 4 (APOE-ع4) allele isoform (Itzhaki et al. 1997; Steel and Eslick 2015). Besides host genetics, HSV infection is known to increase as people age, and women are twice as likely to be infected with HSV-2; both age and gender are known to affect risk for certain neurodegenerative and chronic inflammatory diseases (McQuillan et al. 2018). Given these important genetic, environmental and pathogen factors, mouse models will continue be useful to dissect the cells and pathways that are implicated in HSV infections of the CNS. As novel techniques are applied to study human HSE in rare patients, including induced pluripotent stem cell differentiation of patient cells to CNS cells (Lafaille et al. 2012; Pourchet et al. 2017; Zhang et al. 2018), we expect that these essential genes identified in animal models and human patients will together help to define mechanisms of pathogenesis and viral control, and better clarify how a widespread and successful viral pathogen only seldom results in lethal encephalitis.

Acknowledgements M.M. was supported by the Fonds de recherche santé - Québec (FRQS). S.M.V. was supported by the Canada Research Chairs Program and the Canadian Institutes of Health Research (CIHR).

\section{Compliance with ethical standards}

Conflict of interest On behalf of all authors, the corresponding author states that there is no conflict of interest.

Open Access This article is distributed under the terms of the Creative Commons Attribution 4.0 International License (http://creativeco mmons.org/licenses/by/4.0/), which permits unrestricted use, distribution, and reproduction in any medium, provided you give appropriate credit to the original author(s) and the source, provide a link to the Creative Commons license, and indicate if changes were made.

\section{References}

Ahmed M, Lock M, Miller CG, Fraser NW (2002) Regions of the herpes simplex virus type 1 latency-associated transcript that protect cells from apoptosis in vitro and protect neuronal cells in vivo. J Virol 76:717-729

Aravalli RN, Hu S, Rowen TN, Palmquist JM, Lokensgard JR (2005) Cutting edge: TLR2-mediated proinflammatory cytokine and chemokine production by microglial cells in response to herpes simplex virus. J Immunol (Baltimore, Md: 1950) 175:4189-4193

Aravalli RN, Hu S, Rowen TN, Gekker G, Lokensgard JR (2006) Differential apoptotic signaling in primary glial cells infected with herpes simplex virus 1. J Neurovirol 12:501-510. https://doi. org/10.1080/13550280601064921

Armangue $\mathrm{T}$ et al (2014) Herpes simplex virus encephalitis is a trigger of brain autoimmunity. Ann Neurol 75:317-323. https://doi. org/10.1002/ana.24083
Ashkar AA, Rosenthal KL (2003) Interleukin-15 and natural killer and NKT cells play a critical role in innate protection against genital herpes simplex virus type 2 infection. J Virol 77:10168-10171

Ashley SL et al (2017) Matrix metalloproteinase activity in infections by an encephalitic virus, mouse adenovirus type 1 . J Virol. https ://doi.org/10.1128/jvi.01412-16

Audry M et al (2011) NEMO is a key component of NF-kappaB- and IRF-3-dependent TLR3-mediated immunity to herpes simplex virus. J Allergy Clin Immunol 128:610-617, e611-614. https:// doi.org/10.1016/j.jaci.2011.04.059

Beland JL, Sobel RA, Adler H, Del-Pan NC, Rimm IJ (1999) B cell-deficient mice have increased susceptibility to HSV-1 encephalomyelitis and mortality. J Neuroimmunol 94:122-126

Bergstrom T, Alestig K, Svennerholm B, Horal P, Skoldenberg B, Vahlne A (1990) Neurovirulence of herpes simplex virus types 1 and 2 isolates in diseases of the central nervous system. Eur J Clin Microbiol Infect Dis 9:751-757

Bloomgren $\mathrm{G}$ et al (2012) Risk of natalizumab-associated progressive multifocal leukoencephalopathy. N Engl J Med 366:18701880. https://doi.org/10.1056/NEJMoa1107829

Boivin N, Sergerie Y, Rivest S, Boivin G (2008) Effect of pretreatment with toll-like receptor agonists in a mouse model of herpes simplex virus type 1 encephalitis. J Infect Dis 198:664672. https://doi.org/10.1086/590671

Bryant-Hudson KM, Gurung HR, Zheng M, Carr DJ (2014) Tumor necrosis factor alpha and interleukin-6 facilitate corneal lymphangiogenesis in response to herpes simplex virus 1 infection. J Virol 88:14451-14457. https://doi.org/10.1128/jvi.01841-14

Caignard $\mathrm{G}$ et al (2013) Genome-wide mouse mutagenesis reveals CD45-mediated $\mathrm{T}$ cell function as critical in protective immunity to HSV-1. PLoS Pathog 9:e1003637. https://doi. org/10.1371/journal.ppat.1003637

Cantin E, Tanamachi B, Openshaw H, Mann J, Clarke K (1999) Gamma interferon (IFN-gamma) receptor null-mutant mice are more susceptible to herpes simplex virus type 1 infection than IFN-gamma ligand null-mutant mice. J Virol 73:5196-5200

Carr DJ, Ash J, Lane TE, Kuziel WA (2006) Abnormal immune response of CCR5-deficient mice to ocular infection with herpes simplex virus type 1. J General Virol 87:489-499. https:// doi.org/10.1099/vir.0.81339-0

Casanova JL (2015) Severe infectious diseases of childhood as monogenic inborn errors of immunity. Proc Natl Acad Sci USA 112:E7128-E7137. https://doi.org/10.1073/pnas.1521651112

Casrouge A et al (2006) Herpes simplex virus encephalitis in human UNC-93B deficiency. Science 314:308-312. https://doi. org/10.1126/science.1128346

Chen $M$ et al (2016) TRIM14 inhibits cGAS degradation mediated by selective autophagy receptor p62 to promote innate immune responses. Mol Cell 64:105-119. https://doi.org/10.1016/j. molcel.2016.08.025

Chen Y et al (2017) p38 inhibition provides anti-DNA virus immunity by regulation of USP21 phosphorylation and STING activation. J Exp Med 214:991-1010. https://doi.org/10.1084/ jem. 20161387

Conrady CD, Zheng M, van Rooijen N, Drevets DA, Royer D, Alleman A, Carr DJ (2013) Microglia and a functional type I IFN pathway are required to counter HSV-1-driven brain lateral ventricle enlargement and encephalitis. J Immunol (Baltimore Md: 1950) 190:2807-2817. https://doi.org/10.4049/jimmunol.1203265

Cook ML, Stevens JG (1973) Pathogenesis of herpetic neuritis and ganglionitis in mice: evidence for intra-axonal transport of infection. Infect Immun 7:272-288

da Cunha Sousa LF et al (2016) Suppressor of cytokine signaling 2 (SOCS2) contributes to encephalitis in a model of Herpes infection in mice. Brain Res Bull 127:164-170. https://doi. org/10.1016/j.brainresbull.2016.09.011 
Doll JR, Sawtell NM (2017) Analysis of herpes simplex virus reactivation in explant reveals a method-dependent difference in measured timing of reactivation. J Virol. https://doi.org/10.1128/ jvi.00848-17

Dupuis S et al (2003) Impaired response to interferon-alpha/beta and lethal viral disease in human STAT1 deficiency. Nat Genet 33:388-391. https://doi.org/10.1038/ng1097

Durbin JE, Hackenmiller R, Simon MC, Levy DE (1996) Targeted disruption of the mouse Stat 1 gene results in compromised innate immunity to viral disease. Cell 84:443-450

Fink SL, Jayewickreme TR, Molony RD, Iwawaki T, Landis CS, Lindenbach BD, Iwasaki A (2017) IRE1alpha promotes viral infection by conferring resistance to apoptosis. Sci Signal. https://doi.org/10.1126/scisignal.aai7814

Ghosh S, Wallerath C, Covarrubias S, Hornung V, Carpenter S, Fitzgerald KA (2017) The PYHIN Protein p205 Regulates the Inflammasome by controlling Asc expression. J Immunol (Baltimore Md 1950) 199:3249-3260. https://doi.org/10.4049/ jimmunol.1700823

Gurung HR, Carr MM, Carr DJ (2017) Cornea lymphatics drive the CD8(+) T-cell response to herpes simplex virus-1. Immunol Cell Biol 95:87-98. https://doi.org/10.1038/icb.2016.80

Haarr L, Shukla D, Rodahl E, Dal Canto MC, Spear PG (2001) Transcription from the gene encoding the herpesvirus entry receptor nectin-1 (HveC) in nervous tissue of adult mouse. Virology 287:301-309. https://doi.org/10.1006/viro.2001.1041

Haubenberger D, Clifford DB (2016) Clinical trials in neurovirology: successes, challenges, and pitfalls. Neurotherapeutics 13:571581. https://doi.org/10.1007/s13311-016-0440-8

Herman M et al (2012) Heterozygous TBK1 mutations impair TLR3 immunity and underlie herpes simplex encephalitis of childhood. J Exp Med 209:1567-1582. https://doi.org/10.1084/ jem.20111316

Hertel L, De Andrea M, Azzimonti B, Rolle A, Gariglio M, Landolfo S (1999) The interferon-inducible 204 gene, a member of the Ifi 200 family, is not involved in the antiviral state induction by IFN-alpha, but is required by the mouse cytomegalovirus for its replication. Virology 262:1-8. https://doi.org/10.1006/ viro.1999.9885

Holm TH, Draeby D, Owens T (2012) Microglia are required for astroglial Toll-like receptor 4 response and for optimal TLR2 and TLR3 response. Glia 60:630-638. https://doi.org/10.1002/ glia.22296

Holterman AX, Rogers K, Edelmann K, Koelle DM, Corey L, Wilson CB (1999) An important role for major histocompatibility complex class I-restricted $\mathrm{T}$ cells, and a limited role for gamma interferon, in protection of mice against lethal herpes simplex virus infection. J Virol 73:2058-2063

Honda $\mathrm{K}$ et al (2005) IRF-7 is the master regulator of type-I interferondependent immune responses. Nature 434:772-777. https://doi. org/10.1038/nature03464

Horan KA et al (2013) Proteasomal degradation of herpes simplex virus capsids in macrophages releases DNA to the cytosol for recognition by DNA sensors. J Immunol (Baltimore Md 1950) 190:2311-2319. https://doi.org/10.4049/jimmunol.1202749

Itzhaki RF, Lin WR, Shang D, Wilcock GK, Faragher B, Jamieson GA (1997) Herpes simplex virus type 1 in brain and risk of Alzheimer's disease. Lancet 349:241-244. https://doi.org/10.1016/ s0140-6736(96)10149-5

Jorgensen LK, Dalgaard LS, Ostergaard LJ, Norgaard M, Mogensen TH (2017) Incidence and mortality of herpes simplex encephalitis in Denmark: a nationwide registry-based cohort study. J Infect 74:42-49. https://doi.org/10.1016/j.jinf.2016.09.004

Kaewpoowat Q, Salazar L, Aguilera E, Wootton SH, Hasbun R (2016) Herpes simplex and varicella zoster CNS infections: clinical presentations, treatments and outcomes. Infection 44:337-345. https://doi.org/10.1007/s15010-015-0867-6

Kassim SH, Rajasagi NK, Zhao X, Chervenak R, Jennings SR (2006) In vivo ablation of CD11c-positive dendritic cells increases susceptibility to herpes simplex virus type 1 infection and diminishes NK and T-cell responses. J Virol 80:3985-3993. https:// doi.org/10.1128/jvi.80.8.3985-3993.2006

Kastrukoff LF, Lau AS, Takei F, Carbone FR, Scalzo AA (2015) A NK complex-linked locus restricts the spread of herpes simplex virus type 1 in the brains of C57BL/6 mice. Immunol Cell Biol 93:877-884. https://doi.org/10.1038/icb.2015.54

Katzenell S, Leib DA (2016) Herpes simplex virus and interferon signaling induce novel autophagic clusters in sensory neurons. J Virol 90:4706-4719. https://doi.org/10.1128/jvi.02908-15

Katzenell S, Chen Y, Parker ZM, Leib DA (2014) The differential interferon responses of two strains of Stat1-deficient mice do not alter susceptibility to HSV-1 and VSV in vivo. Virology 450-451:350-354. https://doi.org/10.1016/j.virol.2013.12.015

Kopp SJ et al (2009) Infection of neurons and encephalitis after intracranial inoculation of herpes simplex virus requires the entry receptor nectin-1. Proc Natl Acad Sci USA 106:17916-17920. https://doi.org/10.1073/pnas.0908892106

Koyuncu OO, Hogue IB, Enquist LW (2013) Virus infections in the nervous system. Cell Host Microbe 13:379-393. https://doi. org/10.1016/j.chom.2013.03.010

Kramer T, Enquist LW (2013) Directional spread of alphaherpesviruses in the nervous system. Viruses 5:678-707. https://doi. org/10.3390/v5020678

Kroll CM, Zheng M, Carr DJ (2014) Enhanced resistance of CXCR3 deficient mice to ocular HSV-1 infection is due to control of replication in the brain ependyma. J Neuroimmunol 276:219-223. https://doi.org/10.1016/j.jneuroim.2014.08.005

Kumaraguru U, Davis IA, Deshpande S, Tevethia SS, Rouse BT (2001) Lymphotoxin alpha-/- mice develop functionally impaired $\mathrm{CD} 8+\mathrm{T}$ cell responses and fail to contain virus infection of the central nervous system. J Immunol (Baltimore, Md: 1950) 166:1066-1074

Kurt-Jones EA et al (2004) Herpes simplex virus 1 interaction with Toll-like receptor 2 contributes to lethal encephalitis. Proc Natl Acad Sci USA 101:1315-1320. https://doi.org/10.1073/ pnas.0308057100

Lafaille FG et al (2012) Impaired intrinsic immunity to HSV-1 in human iPSC-derived TLR3-deficient CNS cells. Nature 491:769-773. https://doi.org/10.1038/nature11583

Lahmidi S, Yousefi M, Dridi S, Duplay P, Pearson A (2017) Dok-1 and Dok-2 are required to maintain herpes simplex virus 1-specific CD8(+) T cells in a murine model of ocular infection. J Virol. https://doi.org/10.1128/jvi.02297-16

LeBlanc RA, Pesnicak L, Cabral ES, Godleski M, Straus SE (1999) Lack of interleukin-6 (IL-6) enhances susceptibility to infection but does not alter latency or reactivation of herpes simplex virus type 1 in IL-6 knockout mice. J Virol 73:8145-8151

Lee AJ et al (2017) Inflammatory monocytes require type I interferon receptor signaling to activate NK cells via IL-18 during a mucosal viral infection. J Exp Med 214:1153-1167. https://doi. org/10.1084/jem.20160880

Lenschow DJ et al (2007) IFN-stimulated gene 15 functions as a critical antiviral molecule against influenza, herpes, and Sindbis viruses. Proc Natl Acad Sci USA 104:1371-1376. https://doi. org/10.1073/pnas.0607038104

Li F et al (2015) Viral infection of the Central Nervous System and neuroinflammation precede blood-brain barrier disruption during Japanese Encephalitis. Virus Infect J Virol 89:5602-5614. https ://doi.org/10.1128/jvi.00143-15

Lima GK et al (2010) Toll-like receptor (TLR) 2 and TLR9 expressed in trigeminal ganglia are critical to viral control during herpes 
simplex virus 1 infection. Am J Pathol 177:2433-2445. https:// doi.org/10.2353/ajpath.2010.100121

Lin R, Noyce RS, Collins SE, Everett RD, Mossman KL (2004) The herpes simplex virus ICP0 RING finger domain inhibits IRF3and IRF7-mediated activation of interferon-stimulated genes. J Virol 78:1675-1684

Linder CC (2006) Genetic variables that influence phenotype. ILAR J 47:132-140

Liu Y et al (2016) RIG-I-mediated STING upregulation restricts herpes simplex virus 1 infection. J Virol 90:9406-9419. https://doi. org/10.1128/jvi.00748-16

Livorsi D, Anderson E, Qureshi S, Howard M, Wang YF, Franco-Paredes C (2010) Brainstem encephalitis: an unusual presentation of herpes simplex virus infection. J Neurol 257:1432-1437. https ://doi.org/10.1007/s00415-010-5600-x

Long SS, Pool TE, Vodzak J, Daskalaki I, Gould JM (2011) Herpes simplex virus infection in young infants during 2 decades of empiric acyclovir therapy. Pediatr Infect Dis J 30:556-561. https ://doi.org/10.1097/INF.0b013e31820e3398

Looker KJ, Magaret AS, May MT, Turner KM, Vickerman P, Gottlieb SL, Newman LM (2015a) Global and regional estimates of prevalent and incident herpes simplex virus type 1 infections in 2012. PLoS ONE 10:e0140765. https://doi.org/10.1371/journ al.pone. 0140765

Looker KJ, Magaret AS, Turner KM, Vickerman P, Gottlieb SL, Newman LM (2015b) Correction: global estimates of prevalent and incident herpes simplex virus type 2 infections in 2012. PLoS ONE 10:e0128615. https://doi.org/10.1371/journal.pone.01286 15

Looker KJ, Magaret AS, May MT, Turner KME, Vickerman P, Newman LM, Gottlieb SL (2017) First estimates of the global and regional incidence of neonatal herpes infection. Lancet Global Health 5:e300-e309. https://doi.org/10.1016/s2214 $-109 x(16) 30362-x$

Lopez C (1975) Genetics of natural resistance to herpesvirus infections in mice. Nature 258:152-153

Lopez C (1980) Resistance to HSV-1 in the mouse is governed by two major, independently segregating, non-H-2 loci. Immunogenetics 11:87-92

Louveau A et al (2015) Structural and functional features of central nervous system lymphatic vessels. Nature 523:337-341. https:// doi.org/10.1038/nature14432

Lucinda N et al (2017) Dendritic cells, macrophages, NK and CD8(+) $\mathrm{T}$ lymphocytes play pivotal roles in controlling HSV-1 in the trigeminal ganglia by producing IL1-beta, iNOS and granzyme B. Virol J 14:37. https://doi.org/10.1186/s12985-017-0692-x

Lundberg P, Welander P, Openshaw H, Nalbandian C, Edwards C, Moldawer L, Cantin E (2003) A locus on mouse chromosome 6 that determines resistance to herpes simplex virus also influences reactivation, while an unlinked locus augments resistance of female mice. J Virol 77:11661-11673

Lundberg P, Welander PV, Edwards CK 3rd, van Rooijen N, Cantin E (2007) Tumor necrosis factor (TNF) protects resistant C57BL/6 mice against herpes simplex virus-induced encephalitis independently of signaling via TNF receptor 1 or 2 . J Virol 81:14511460. https://doi.org/10.1128/jvi.02243-06

Lundberg P et al (2008) The immune response to herpes simplex virus type 1 infection in susceptible mice is a major cause of central nervous system pathology resulting in fatal encephalitis. J Virol 82:7078-7088. https://doi.org/10.1128/jvi.00619-08

Luo WW, Li S, Li C, Lian H, Yang Q, Zhong B, Shu HB (2016) iRhom 2 is essential for innate immunity to DNA viruses by mediating trafficking and stability of the adaptor STING. Nat Immunol 17:1057-1066. https://doi.org/10.1038/ni.3510

MacLean A, Wei XQ, Huang FP, Al-Alem UA, Chan WL, Liew FY (1998) Mice lacking inducible nitric-oxide synthase are more susceptible to herpes simplex virus infection despite enhanced Th1 cell responses. J General Virol 79(Pt 4):825-830. https://doi. org/10.1099/0022-1317-79-4-825

Manickan E, Rouse BT (1995) Roles of different T-cell subsets in control of herpes simplex virus infection determined by using T-celldeficient mouse-models. J Virol 69:8178-8179

Manivanh R, Mehrbach J, Knipe DM, Leib DA (2017) Role of herpes simplex virus 1 gamma34.5 in the regulation of IRF3 signaling. J Virol. https://doi.org/10.1128/jvi.01156-17

Mansur DS et al (2005) Lethal encephalitis in myeloid differentiation factor 88-deficient mice infected with herpes simplex virus 1. Am J Pathol 166:1419-1426. https://doi.org/10.1016/s0002 $-9440(10) 62359-0$

Marques CP, Cheeran MC, Palmquist JM, Hu S, Urban SL, Lokensgard JR (2008) Prolonged microglial cell activation and lymphocyte infiltration following experimental herpes encephalitis. J Immunol (Baltimore, Md: 1950) 181:6417-6426

Maruzuru Y, Fujii H, Oyama M, Kozuka-Hata H, Kato A, Kawaguchi Y (2013) Roles of p53 in herpes simplex virus 1 replication. J Virol 87:9323-9332. https://doi.org/10.1128/jvi.01581-13

Maruzuru Y et al (2016) p53 is a host cell regulator during herpes simplex encephalitis. J Virol 90:6738-6745. https://doi.org/10.1128/ jvi.00846-16

Matundan HH et al (2016) Interrelationship of primary virus replication, level of latency, and time to reactivation in the trigeminal ganglia of latently infected mice. J Virol 90:9533-9542. https:// doi.org/10.1128/jvi.01373-16

McQuillan G, Kruszon-Moran D, Flagg EW, Paulose-Ram R (2018) Prevalence of herpes simplex virus type 1 and type 2 in persons aged 14-49: United States, 2015-2016. NCHS Data Brief 304:1-8

Menasria R, Boivin N, Lebel M, Piret J, Gosselin J, Boivin G (2013) Both TRIF and IPS-1 adaptor proteins contribute to the cerebral innate immune response against herpes simplex virus 1 infection. J Virol 87:7301-7308. https://doi.org/10.1128/jvi.00591-13

Menasria R, Canivet C, Piret J, Boivin G (2015) Infiltration pattern of blood monocytes into the Central Nervous System during experimental herpes simplex virus encephalitis. PLoS ONE 10:e0145773. https://doi.org/10.1371/journal.pone.0145773

Menasria R, Canivet C, Piret J, Gosselin J, Boivin G (2017) Protective role of CX3CR1 signalling in resident cells of the central nervous system during experimental herpes simplex virus encephalitis. J General Virol 98:447-460. https://doi.org/10.1099/jgv.0.000667

Menendez CM, Carr DJJ (2017) Defining nervous system susceptibility during acute and latent herpes simplex virus-1 infection. J Neuroimmunol 308:43-49. https://doi.org/10.1016/j.jneur oim.2017.02.020

Meraz MA et al (1996) Targeted disruption of the Stat 1 gene in mice reveals unexpected physiologic specificity in the JAK-STAT signaling pathway. Cell 84:431-442

Michael BD et al (2016) The interleukin-1 balance during encephalitis is associated with clinical severity, blood-brain barrier permeability, neuroimaging changes, and disease outcome. J Infect Dis 213:1651-1660. https://doi.org/10.1093/infdis/jiv771

Milora KA, Uppalapati SR, Sanmiguel JC, Zou W, Jensen LE (2017) Interleukin-36beta provides protection against HSV-1 infection, but does not modulate initiation of adaptive immune responses. Sci Rep 7:5799. https://doi.org/10.1038/s41598-017-05363-4

Mohankrishnan A, Parmar R, Bhurani V, Dalai SK (2017) Lack of TNF-alpha signaling through 555 makes the mice more susceptible to acute infection but does not alter state of latency and reactivation of HSV-1. Virus Res 244:1-5. https://doi.org/10.1016/j. virusres.2017.11.004

Murphy AA, Rosato PC, Parker ZM, Khalenkov A, Leib DA (2013) Synergistic control of herpes simplex virus pathogenesis by IRF3 , and IRF-7 revealed through non-invasive bioluminescence 
imaging. Virology 444:71-79. https://doi.org/10.1016/j.virol 2013.05.034

Oh JE, Lee MS, Kim YJ, Lee HK (2016) OASL1 deficiency promotes antiviral protection against genital herpes simplex virus type 2 infection by enhancing type I interferon production. Sci Rep 6:19089. https://doi.org/10.1038/srep19089

Omae T, Saito Y, Tsuchie H, Ohno K, Maegaki Y, Sakuma H (2018) Cytokine/chemokine elevation during the transition phase from HSV encephalitis to autoimmune anti-NMDA receptor encephalitis. Brain Dev 40:361-365. https://doi.org/10.1016/j.brain dev.2017.12.007

Orvedahl A et al (2007) HSV-1 ICP34.5 confers neurovirulence by targeting the Beclin 1 autophagy protein. Cell Host Microbe 1:23-35. https://doi.org/10.1016/j.chom.2006.12.001

Pandey U, Renner DW, Thompson RL, Szpara ML, Sawtell NM (2017) Inferred father-to-son transmission of herpes simplex virus results in near-perfect preservation of viral genome identity and in vivo phenotypes. Sci Rep 7:13666. https://doi.org/10.1038/ s41598-017-13936-6

Parker ZM, Murphy AA, Leib DA (2015) Role of the DNA sensor STING in protection from lethal infection following corneal and intracerebral challenge with herpes simplex virus 1 . J Virol 89:11080-11091. https://doi.org/10.1128/jvi.00954-15

Parker ZM, Pasieka TJ, Parker GA, Leib DA (2016) Immune- and nonimmune-compartment-specific interferon responses are critical determinants of herpes simplex virus-induced generalized infections and acute liver failure. J Virol 90:10789-10799. https ://doi.org/10.1128/jvi.01473-16

Parsons LR, Tafuri YR, Shreve JT, Bowen CD, Shipley MM, Enquist LW, Szpara ML (2015) Rapid genome assembly and comparison decode intrastrain variation in human alphaherpesviruses. MBio https://doi.org/10.1128/mBio.02213-14

Pasieka TJ, Cilloniz C, Lu B, Teal TH, Proll SC, Katze MG, Leib DA (2009) Host responses to wild-type and attenuated herpes simplex virus infection in the absence of Stat1. J Virol 83:20752087. https://doi.org/10.1128/jvi.02007-08

Pasieka TJ, Cilloniz C, Carter VS, Rosato P, Katze MG, Leib DA (2011a) Functional genomics reveals an essential and specific role for Stat 1 in protection of the central nervous system following herpes simplex virus corneal infection. J Virol 85:1297212981. https://doi.org/10.1128/jvi.06032-11

Pasieka TJ et al (2011b) Bioluminescent imaging reveals divergent viral pathogenesis in two strains of Stat1-deficient mice, and in alphassgamma interferon receptor-deficient mice. PLoS ONE 6:e24018. https://doi.org/10.1371/journal.pone.0024018

Perez de Diego R et al (2010) Human TRAF3 adaptor molecule deficiency leads to impaired Toll-like receptor 3 response and susceptibility to herpes simplex encephalitis. Immunity 33:400-411. https://doi.org/10.1016/j.immuni.2010.08.014

Pestka S, Krause CD, Walter MR (2004) Interferons, interferon-like cytokines, and their receptors. Immunol Rev 202:8-32. https:// doi.org/10.1111/j.0105-2896.2004.00204.x

Petermann P, Rahn E, Thier K, Hsu MJ, Rixon FJ, Kopp SJ, KnebelMorsdorf D (2015a) Role of nectin-1 and herpesvirus entry mediator as cellular receptors for herpes simplex virus 1 on primary murine dermal fibroblasts. J Virol 89:9407-9416. https:// doi.org/10.1128/jvi.01415-15

Petermann P et al (2015b) Entry mechanisms of herpes simplex virus 1 into murine epidermis: involvement of nectin- 1 and herpesvirus entry mediator as cellular receptors. J Virol 89:262-274. https:// doi.org/10.1128/jvi.02917-14

Pourchet A, Modrek AS, Placantonakis DG, Mohr I, Wilson AC (2017) Modeling HSV-1 latency in human embryonic stem cell-derived neurons. Pathogens. https://doi.org/10.3390/pathogens6020024
Quenelle DC et al (2018) Efficacy of pritelivir and acyclovir in the treatment of herpes simplex virus infections in a mouse model of herpes simplex encephalitis. Antiviral Res 149:1-6. https:// doi.org/10.1016/j.antiviral.2017.11.002

Ramakrishna C, Cantin EM (2018) IFNgamma inhibits G-CSF induced neutrophil expansion and invasion of the CNS to prevent viral encephalitis. PLoS Pathog 14:e1006822. https://doi.org/10.1371/ journal.ppat.1006822

Ramakrishna C et al (2015) Establishment of HSV1 latency in immunodeficient mice facilitates efficient in vivo reactivation. PLoS Pathog 11:e1004730. https://doi.org/10.1371/journal.ppat.10047 30

Reinert LS et al (2012) TLR3 deficiency renders astrocytes permissive to herpes simplex virus infection and facilitates establishment of CNS infection in mice. J Clin Investig 122:1368-1376. https:// doi.org/10.1172/jci60893

Reinert LS et al (2016) Sensing of HSV-1 by the cGAS-STING pathway in microglia orchestrates antiviral defence in the CNS. Nat Commun 7:13348. https://doi.org/10.1038/ncomms 13348

Rochfort KD, Collins LE, McLoughlin A, Cummins PM (2016) Tumour necrosis factor-alpha-mediated disruption of cerebrovascular endothelial barrier integrity in vitro involves the production of proinflammatory interleukin-6. J Neurochem 136:564-572. https://doi.org/10.1111/jnc. 13408

Rosato PC, Leib DA (2014) Intrinsic innate immunity fails to control herpes simplex virus and vesicular stomatitis virus replication in sensory neurons and fibroblasts. J Virol 88:9991-10001. https:// doi.org/10.1128/jvi.01462-14

Rosato PC, Katzenell S, Pesola JM, North B, Coen DM, Leib DA (2016) Neuronal IFN signaling is dispensable for the establishment of HSV-1 latency. Virology 497:323-327. https://doi. org/10.1016/j.virol.2016.06.016

Rosenberger K, Derkow K, Dembny P, Kruger C, Schott E, Lehnardt S (2014) The impact of single and pairwise Toll-like receptor activation on neuroinflammation and neurodegeneration. J Neuroinflamm 11:166. https://doi.org/10.1186/s12974-014-0166-7

Sagnelli E, Sagnelli C, Macera M, Pisaturo M, Coppola N (2017) An update on the treatment options for $\mathrm{HBV} / \mathrm{HCV}$ coinfection. Expert Opin Pharmacother 18:1691-1702. https://doi. org/10.1080/14656566.2017.1398233

Salimi H, Cain MD, Klein RS (2016) Encephalitic arboviruses: emergence, clinical presentation, and neuropathogenesis. Neurotherapeutics 13:514-534. https://doi.org/10.1007/s13311-016-0443-5

Sancho-Shimizu V et al (2011) Herpes simplex encephalitis in children with autosomal recessive and dominant TRIF deficiency. J Clin Investig 121:4889-4902. https://doi.org/10.1172/jci59259

Schacker TW, Conant M, Thoming C, Stanczak T, Wang Z, Smith M (2002) Imiquimod 5-percent cream does not alter the natural history of recurrent herpes genitalis: a phase II, randomized, double-blind, placebo-controlled study. Antimicrob Agents Chemother 46:3243-3248

Sellner J, Simon F, Meyding-Lamade U, Leib SL (2006) Herpessimplex virus encephalitis is characterized by an early MMP-9 increase and collagen type IV degradation. Brain Res 1125:155162. https://doi.org/10.1016/j.brainres.2006.09.093

Sergerie Y, Rivest S, Boivin G (2007) Tumor necrosis factor-alpha and interleukin-1 beta play a critical role in the resistance against lethal herpes simplex virus encephalitis. J Infect Dis 196:853860. https://doi.org/10.1086/520094

Shivkumar M, Milho R, May JS, Nicoll MP, Efstathiou S, Stevenson PG (2013) Herpes simplex virus 1 targets the murine olfactory neuroepithelium for host entry. J Virol 87:10477-10488. https:// doi.org/10.1128/jvi.01748-13

Skouboe MK et al (2018) STING agonists enable antiviral cross-talk between human cells and confer protection against genital herpes 
in mice. PLoS Pathog 14:e1006976. https://doi.org/10.1371/ journal.ppat.1006976

Solomon T et al (2012) Management of suspected viral encephalitis in adults - association of British Neurologists and British Infection Association National Guidelines. J Infect 64:347-373. https:// doi.org/10.1016/j.jinf.2011.11.014

Song G et al (2016) E3 ubiquitin ligase RNF128 promotes innate antiviral immunity through K63-linked ubiquitination of TBK1. Nat Immunol 17:1342-1351. https://doi.org/10.1038/ni.3588

Steel AJ, Eslick GD (2015) Herpes viruses increase the risk of alzheimer's disease: a meta-analysis. J Alzheimers Dis 47:351-364. https://doi.org/10.3233/jad-140822

Steiner I (2011) Herpes simplex virus encephalitis: new infection or reactivation? Curr Opin Neurol 24:268-274. https://doi. org/10.1097/WCO.0b013e328346be6f

Steiner I, Benninger F (2013) Update on herpes virus infections of the nervous system. Curr Neurol Neurosci Rep 13:414. https://doi. org/10.1007/s11910-013-0414-8

Sun $\mathrm{H}$ et al (2017a) USP13 negatively regulates antiviral responses by deubiquitinating STING. Nat Commun 8:15534. https://doi. org/10.1038/ncomms 15534

Sun L et al (2017b) HCFC2 is needed for IRF1- and IRF2-dependent Tlr3 transcription and for survival during viral infections. J Exp Med 214:3263-3277. https://doi.org/10.1084/jem.20161630

Swiecki M, Wang Y, Gilfillan S, Colonna M (2013) Plasmacytoid dendritic cells contribute to systemic but not local antiviral responses to HSV infections. PLoS Pathog 9:e1003728. https:// doi.org/10.1371/journal.ppat.1003728

Tajfirouz D, West DM, Yin XT, Potter CA, Klein R, Stuart PM (2017) CXCL9 compensates for the absence of CXCL10 during recurrent Herpetic stromal keratitis. Virology 506:7-13. https://doi. org/10.1016/j.virol.2017.02.022

Uyangaa E, Kim JH, Patil AM, Choi JY, Kim SB, Eo SK (2015) Distinct upstream role of type I IFN signaling in hematopoietic stem cell-derived and epithelial resident cells for concerted recruitment of Ly-6Chi monocytes and NK cells via CCL2-CCL3 cascade. PLoS Pathog 11:e1005256. https://doi.org/10.1371/journ al.ppat. 1005256

Vilela MC et al (2013) Absence of CCR5 increases neutrophil recruitment in severe herpetic encephalitis. BMC Neurosci 14:19. https ://doi.org/10.1186/1471-2202-14-19

Vilela MC et al (2016) Platelet activating factor (PAF) receptor deletion or antagonism attenuates severe HSV-1 meningoencephalitis. J Neuroimmune Pharmacol 11:613-621. https://doi.org/10.1007/ s11481-016-9684-7

Wang JP et al (2012) Role of specific innate immune responses in herpes simplex virus infection of the central nervous system. J Virol 86:2273-2281. https://doi.org/10.1128/jvi.06010-11

Wang H, Davido DJ, Morrison LA (2013) HSV-1 strain McKrae is more neuroinvasive than HSV-1 KOS after corneal or vaginal inoculation in mice. Virus Res 173:436-440. https://doi. org/10.1016/j.virusres.2013.01.001

Wang X et al (2016) STING requires the adaptor TRIF to trigger innate immune responses to microbial infection. Cell Host Microbe 20:329-341. https://doi.org/10.1016/j.chom.2016.08.002

Wickham S, Lu B, Ash J, Carr DJ (2005) Chemokine receptor deficiency is associated with increased chemokine expression in the peripheral and central nervous systems and increased resistance to herpetic encephalitis. J Neuroimmunol 162:51-59. https://doi. org/10.1016/j.jneuroim.2005.01.001

Wilcox DR, Wadhwani NR, Longnecker R, Muller WJ (2015) Differential reliance on autophagy for protection from HSV encephalitis between newborns and adults. PLoS Pathog 11:e1004580. https ://doi.org/10.1371/journal.ppat.1004580

Wnek M et al (2016) Herpes simplex encephalitis is linked with selective mitochondrial damage; a post-mortem and in vitro study. Acta Neuropathol 132:433-451. https://doi.org/10.1007/s0040 1-016-1597-2

Wuest TR, Carr DJ (2008) Dysregulation of CXCR3 signaling due to CXCL10 deficiency impairs the antiviral response to herpes simplex virus 1 infection. J Immunol (Baltimore, Md: 1950) 181:7985-7993

Wuest TR, Thapa M, Zheng M, Carr DJ (2011) CXCL10 expressing hematopoietic-derived cells are requisite in defense against HSV-1 infection in the nervous system of CXCL10 deficient mice. J Neuroimmunol 234:103-108. https://doi.org/10.1016/j. jneuroim.2011.03.006

Yakoub AM, Shukla D (2015) Autophagy stimulation abrogates herpes simplex virus-1 infection. Sci Rep 5:9730. https://doi. org/10.1038/srep09730

Yordy B, Iijima N, Huttner A, Leib D, Iwasaki A (2012) A neuronspecific role for autophagy in antiviral defense against herpes simplex virus. Cell Host Microbe 12:334-345. https://doi. org/10.1016/j.chom.2012.07.013

Yu CR, Dambuza IM, Lee YJ, Frank GM, Egwuagu CE (2013) STAT3 regulates proliferation and survival of $\mathrm{CD} 8+\mathrm{T}$ cells: enhances effector responses to HSV-1 infection, and inhibits IL-10+ regulatory CD8+ T cells in autoimmune uveitis. Mediat Inflamm 2013:359674. https://doi.org/10.1155/2013/359674

Zhang SY et al (2007) TLR3 deficiency in patients with herpes simplex encephalitis. Science 317:1522-1527. https://doi.org/10.1126/ science. 1139522

Zhang M, Covar J, Zhang NY, Chen W, Marshall B, Mo J, Atherton SS (2013a) Virus spread and immune response following anterior chamber inoculation of HSV-1 lacking the Beclin-binding domain (BBD). J Neuroimmunol 260:82-91. https://doi. org/10.1016/j.jneuroim.2013.03.013

Zhang SY, Abel L, Casanova JL (2013b) Mendelian predisposition to herpes simplex encephalitis. Handb Clin Neurol 112:1091-1097. https://doi.org/10.1016/b978-0-444-52910-7.00027-1

Zhang SY et al (2018) Inborn errors of RNA lariat metabolism in humans with brainstem viral infection. Cell 172:952-965.e918. https://doi.org/10.1016/j.cell.2018.02.019

Zimmermann J et al (2017) Enhanced viral clearance and reduced leukocyte infiltration in experimental herpes encephalitis after intranasal infection of CXCR3-deficient mice. J Neurovirol 23:394-403. https://doi.org/10.1007/s13365-016-0508-6

Zolini GP et al (2014) Defense against HSV-1 in a murine model is mediated by iNOS and orchestrated by the activation of TLR2 and TLR9 in trigeminal ganglia. J Neuroinflamm 11:20. https:// doi.org/10.1186/1742-2094-11-20 